\title{
51. TECTONIC EVOLUTION AND SUBSIDENCE HISTORY OF THE RIO GRANDE RISE1
}

\author{
Peter F. Barker, Department of Geological Science, Birmingham University, P.O. Box 363, \\ Birmingham, B15 2TT England
}

\begin{abstract}
Drilling at Site 516 on the northern shoulder of the main Rio Grande Rise has improved our understanding of the tectonic evolution and subsidence history of the Rise and of the entire Rio Grande-Walvis seamount and aseismic ridge system. Evidence from this site indicates that basalts at the bottom of Hole $516 \mathrm{~F}$ were produced at the ridge crest and that the ridge crest was subaerial. I attribute the anomalous elevation of the Rise to an eastward ridge crest jump to the western end of the Rise, $91 \mathrm{Ma}$, and, recognizing a southward progression of such eastward jumps, I suggest a model for the Rio Grande-Walvis system involving a slow westward component of drift of the ridge crest off a hot-spot swell. This drift caused off-axis volcanism that in the Cretaceous succeeded but in the Cenozoic failed to capture the ridge crest. The probable mechanism of capture involved counteraction of the ridge push force within the lithosphere by a swell push force. This would make capture more likely in lithosphere produced by fast spreading, perhaps explaining the change of mode at the end of the Cretaceous.

Within the pelagic carbonate sedimentary succession at Site 516, the partly volcaniclastic, turbiditic middle Eocene Unit 4 contains volcanic ash beds (yielding a $47.4 \pm 0.7 \mathrm{Ma} \mathrm{K}$-Ar age from fresh alkalic biotite) and a 15 -m-thick basal slide. Reflection profiles show it was produced by sliding from and by subaerial erosion of a large tilted and uplifted guyot upslope from the site. Data from the site suggest that a single short off-axis event affected the entire crestal region of the Rise. Perhaps the same midplate hot spot that produced an 80-50 Ma volcanic episode in the Serra Geral of Brazil was responsible, but that was not the present Tristan hot spot.

The data from Site 516 have been incorporated into a detailed model for the subsidence history of the main body of the Rise. The model uses an "oceanic" thermal isostatic model, but accounts for the effect of subaerial subsidence and incorporates the changes of the middle Eocene event. A detailed sediment compaction model is developed, and a smooth eustatic sea level correction is applied. The effects of "basement compaction" and use of local rather than regional isostatic compensation are assessed each at about $50 \mathrm{~m}$. The computed paleodepth at Site 516 ranges from sea level $84.0 \mathrm{Ma}$ through a Paleocene $1250 \mathrm{~m}$ maximum and middle Eocene $600 \mathrm{~m}$ minimum to $1313 \mathrm{~m}$ today. The "tectonic" depth curves for both Sites 516 and 357 are compared with paleoecologic depth estimates. In general, these paleoecologic estimates lie deeper, probably because of the difficulties of applying accurate subsidence and compaction corrections to the comparison sites.
\end{abstract}

\section{INTRODUCTION}

The Rio Grande Rise, a substantial body with almost $4000 \mathrm{~m}$ of relief, is part of the Rio Grande-Walvis system of seamounts and aseismic ridges in the South Atlantic (Figure 1). Its present major influence on the circulation of deep and bottom waters would have been even greater in the past, when the South Atlantic was narrower. The Rise also forms a useful mid-oceanic sediment sampler of all the water masses it intersects, away from the less stable and less representative continental margin environment. For these reasons, an understanding of its tectonic evolution is an important component of any model of South Atlantic paleoceanographic development.

The state of knowledge of Rio Grande Rise tectonics, as it was in about 1980 , is described in one of the introductory chapters (Barker and Carlson, this volume). The consensus was that the Rise had formed at or very close to the mid-ocean ridge crest in the Late Cretaceous (Cenomanian), as a 2000-m-high oceanic island or island group, and that it had subsided steadily ever since, after the manner of normal oceanic lithosphere. Such a model

\footnotetext{
${ }^{1}$ Barker, P. F., Carlson, R. L., Johnson, D. A., et al., Init. Repts. DSDP, 72: Washington (U.S. Govt. Printing Office).
}

fits the existing data only by exploiting the considerable uncertainty that those data possess; the need for better constraints was widely recognized. Thus, further investigation of the tectonic evolution of the Rio Grande Rise became an important objective of DSDP Leg 72, the second of five consecutive South Atlantic legs aimed at understanding the developing oceanography of a widening meridional ocean. Because of the extension to igneous basement of drilling on the northern shoulder of the Rise, Site 516 was the deepest and most time-consuming of the four sites drilled and the main achievement of Leg 72 .

The results of drilling at Site 516, not only the chemical analyses and radiometric age determinations, stratigraphic and paleoecological interpretations of the cores but also the associated seismic reflection profiles, newly calibrated, are considerable contributions towards our understanding of the origin and evolution of the Rise. This paper attempts to evaluate and synthesize those contributions and to assess the significance of the conclusions for the evolution of the entire Rio GrandeWalvis system. The second objective, the construction of a subsidence history for Site 516 and vicinity, was attempted in order to provide precise depth calibration for the sedimentary section there, which was continuously cored and showed virtually continuous pelagic carbonate deposition and good preservation. Considerable de- 


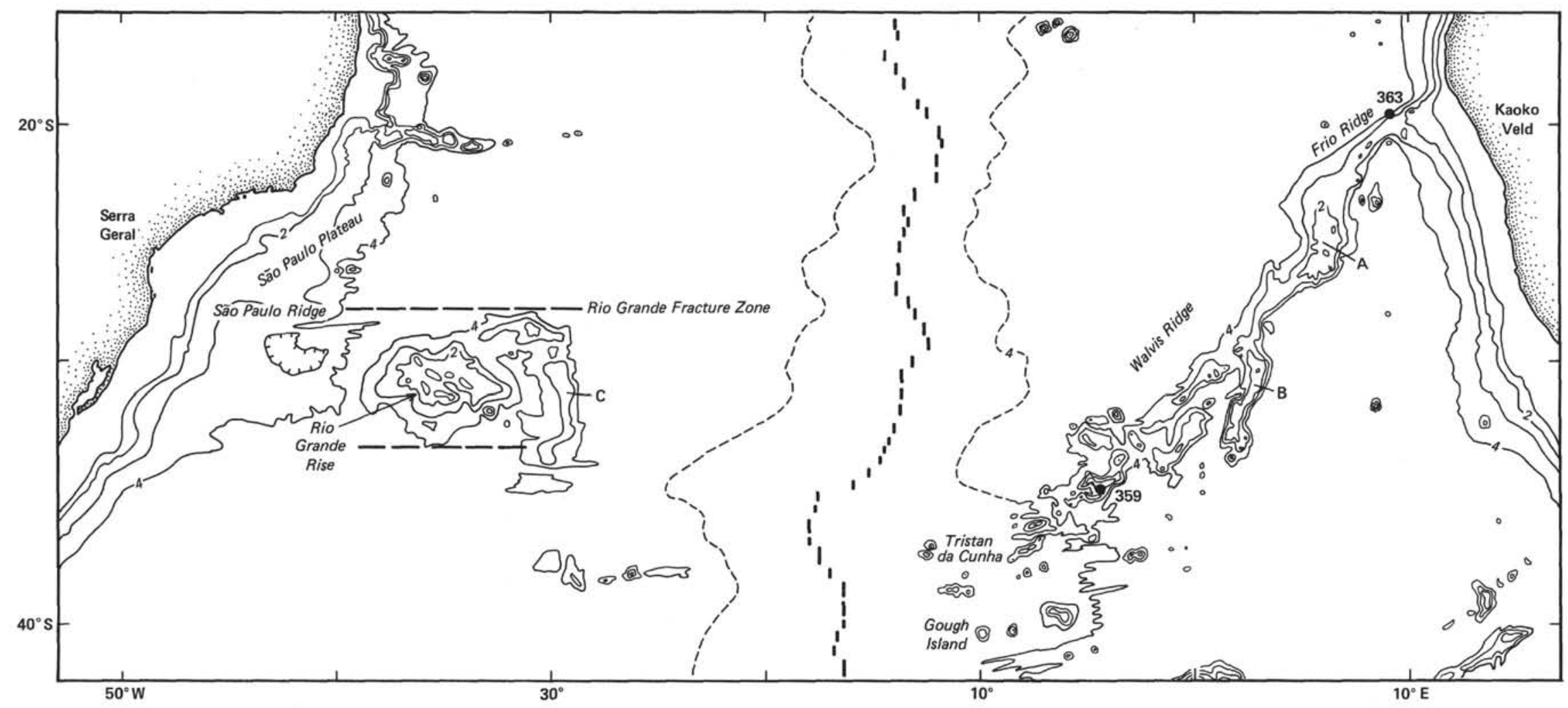

Figure 1. Bathymetry of South Atlantic contoured at 1-km intervals, $4 \mathrm{~km}$ and above (after Uchupi, 1979). Mid-ocean ridge is shown by thick discontinuous central line and smoothed dashed 4-km contour. Tristan da Cunha hot-spot swell is illustrated by greater breadth of area inside 4-km contour. Areas A, B, and C are discussed in the text. 
tail is given here so that any later improvements will be easier to apply.

\section{DRILLING AT SITE 516}

Site 516 is located on the northern shoulder of the main body of the Rio Grande Rise, close to DSDP Sites 22 and 357 (Fig. 2). Drilling penetrated $1252 \mathrm{~m}$ of largely pelagic carbonate sediments and $19 \mathrm{~m}$ into the underlying basaltic basement. Coring was continuous and recovery high, but an attempt to log the hole failed because of deteriorating hole conditions. The section is summarized in Table 1. The most important tectonic features of the section are the nature and age of the basal volcanics and the anomalous, partly volcanogenic middle Eocene Unit 4.

\section{Volcanic Basement, Age and Paleodepth}

Two flow units were penetrated; both are basaltic, mainly plagioclase-phyric, and vesicular, veined, and altered. Neither unit shows quench structures typical of deep ocean lavas: the fine-grained altered groundmass may indicate shallow-water eruption, but the degree of alteration makes this uncertain. The basalts are tholeiitic, quite distinct from the alkalic lavas previously reported from a dredge site on the Rio Grande Rise (Fodor, Husler, and Kumar, 1977) and from those described from Tristan da Cunha. They are mildly enriched in light rare-earth elements (LREE), and their trace element chemistry is characteristic of transitional midocean ridge basalt (T-type MORB, Weaver et al., this volume). Thompson and others (this volume) note their similarity to basalts from the eastern end of the Walvis Ridge (Humphris and Thompson, 1982), which are of a similar age. Only one of the four samples subjected to
${ }^{40} \mathrm{Ar} /{ }^{39} \mathrm{Ar}$ analysis satisfied the generally accepted criteria for a meaningful age, presumably because of the degree of their alteration (Mussett and Barker, this volume); the computed age was $86 \pm 4 \mathrm{Ma}$. An attempt was made to supplement these data, exploiting the recent demonstration that $\mathrm{Rb}-\mathrm{Sr}$ ages of secondary vein minerals in ocean floor basalts are very close to the age of primary volcanism (Hart and Staudigel, 1978), but the age determined from celadonite and calcite filling veins in Core 516F-126 (Hart and Staudigel, this volume) was $68.7 \pm 1.5 \mathrm{Ma}$. This isochron is well-defined, suggesting a single, short hydrothermal event, but its tectonic significance is uncertain and other age data are less precise. The basalt is normally magnetized and a magnetic reversal, identified with Anomaly 34 , is found in Core 516F-119. The deepest biostratigraphic control is provided by nannofossils in Section 516F-124-2 (Marthasterites furcatus Zone, Santonian-Coniacian).

The identification of Magnetic Anomalies 33 and 34 to the east of Site 516 (Fig. 2) is tentative, because the shallow depth to basement on the flank of the Rio Grande Rise makes the anomalies atypically sharp (Cande and Rabinowitz, 1979). Also, the Rio Grande Rise itself, which this identification places within the area formed during the Cretaceous normal magnetic polarity interval, is magnetically disturbed; therefore, some or all of the Rise (including where the identified anomalies lie) may have been produced by off-axis volcanism. If, encouraged by the Site 516 basement chemistry, we assume that the anomaly identifications are correct, then Rabinowitz and LaBrecque's (1979) poles and rates of South Atlantic opening produce an estimate of $84.5 \pm 0.5 \mathrm{Ma}$ for the age of the mid-ocean ridge crest at Site 516. The quoted uncertainty stems partly from

Table 1. Lithology of Hole 516F sediments.

\begin{tabular}{|c|c|c|c|}
\hline Unit & $\begin{array}{l}\text { Interval } \\
(\mathrm{m})\end{array}$ & Age & Description \\
\hline 1 & $0-193$ & $\begin{array}{l}\text { Holocene to early } \\
\text { Miocene }\end{array}$ & $\begin{array}{l}\text { Foraminiferal and nannofossil ooze, pale brown to white; foraminiferal sand } \\
\text { layers occur near } 65 \mathrm{~m} \text {. }\end{array}$ \\
\hline 2 & 193-332 & $\begin{array}{l}\text { early Miocene to late } \\
\text { Oligocene }\end{array}$ & $\begin{array}{l}\text { Light gray nannofossil ooze and chalk with chert nodules and biogenic silica; unit } \\
\text { boundaries defined by shallowest and deepest occurrences of chert. }\end{array}$ \\
\hline 3 & $332-634$ & $\begin{array}{l}\text { late Oligocene to middle } \\
\text { Eocene }\end{array}$ & $\begin{array}{l}\text { Light gray to greenish gray chalk and limestone; parallel laminations common } \\
\text { below } 470 \mathrm{~m} \text {; extensive burrowing throughout. }\end{array}$ \\
\hline 4 & 634-874 & middle Eocene & $\begin{array}{l}\text { Interbedded pelagic limestone, volcanic ash layers, and allochthonous turbidites and } \\
\text { breccias; limestones are generally similar to Unit } 3 \text {, although } \mathrm{CaCO}_{3} \text { decreases } \\
\text { down section toward marly limestone }\left(<60 \% \mathrm{CaCO}_{3}\right) \text {. Ash layers are com- } \\
\text { monly altered to bentonite. Displaced units are variable in composition and } \\
\text { structure, including carbonate and volcanogenic components, graded sequences } \\
\text { and upgraded breccias, and some with mud clasts. Unit boundaries are (1) up- } \\
\text { permost turbidite layer and (2) the base of Maestrichtian limestone slumped } \\
\text { block. Amorphous silica cement is present below } 800 \mathrm{~m} \text {. Physical properties } \\
\text { show a transition to high density and velocity down section within the lime- } \\
\text { stone units of Unit } 4 \text { and a sharp decrease in both at the base. }\end{array}$ \\
\hline 5 & $874-1000$ & $\begin{array}{l}\text { middle Eocene to late } \\
\text { Maestrichtian }\end{array}$ & $\begin{array}{l}\text { Nannofossil limestones, grading from light gray at the top of the unit to reddish } \\
\text { brown below } 930 \mathrm{~m} \text {. Anastomosing laminations (microstyolites) are common }\end{array}$ \\
\hline $5 a$ & $874-930$ & & throughout. This unit contains the Cretaceous/Tertiary boundary in Core 89 , \\
\hline $5 b$ & $930-1000$ & & $\begin{array}{l}\text { within which lithologic variability is striking (clay, marl, and limestone units } \\
\text { interbedded). The uppermost } 40 \mathrm{~m} \text { of Unit } 5 \text { contains amorphous silica, ap- } \\
\text { parently remobilized from the volcanics of Unit } 4 \text {. Kaolinite and illite are pres- } \\
\text { ent in Subunit } 5 \text { b, but not above. }\end{array}$ \\
\hline 6 & $1000-1240$ & $\begin{array}{l}\text { late Maestrichtian to } \\
\text { Coniacian-Santonian }\end{array}$ & $\begin{array}{l}\text { Greenish gray and reddish brown limestones and interbedded marly limestones in } \\
\text { Subunit 6a; greenish gray to dark gray recrystallized dolomitic limestones in }\end{array}$ \\
\hline $6 \mathrm{a}$ & $1000-1130$ & & Subunit $6 \mathrm{~b}$. Bioturbation within both reddish and greenish intervals argues \\
\hline $6 \mathrm{~b}$ & $1130-1240$ & & $\begin{array}{l}\text { against anoxic conditions of deposition of Unit } 6 \text {. Inoceramus fragments are } \\
\text { abundant below } 1150 \mathrm{~m} \text {, with scattered occurrence as shallow as } 1080 \mathrm{~m} \text {. }\end{array}$ \\
\hline 7 & $1240-1251$ & Coniacian-Santonian & $\begin{array}{l}\text { Varicolored volcanic and calcareous turbidites and breccias. The uppermost sedi- } \\
\text { ment recovered in Core } 124 \text { consists of four cobbles of ferruginous chert, under- } \\
\text { lain by a } 20-\mathrm{cm} \text {-thick reddish limestone (probably pelagic) containing In- } \\
\text { oceramus fragments. The remaining sediments of Cores } 124 \text { and } 125 \text { are dis- } \\
\text { placed from shallower sites. }\end{array}$ \\
\hline 8 & $1251-1271$ & & $\begin{array}{l}\text { Olivine-plagioclase phyric tholeitic basalt; calcitic vein filling contains fragments of } \\
\text { coralline algae and bryozoa. }\end{array}$ \\
\hline
\end{tabular}




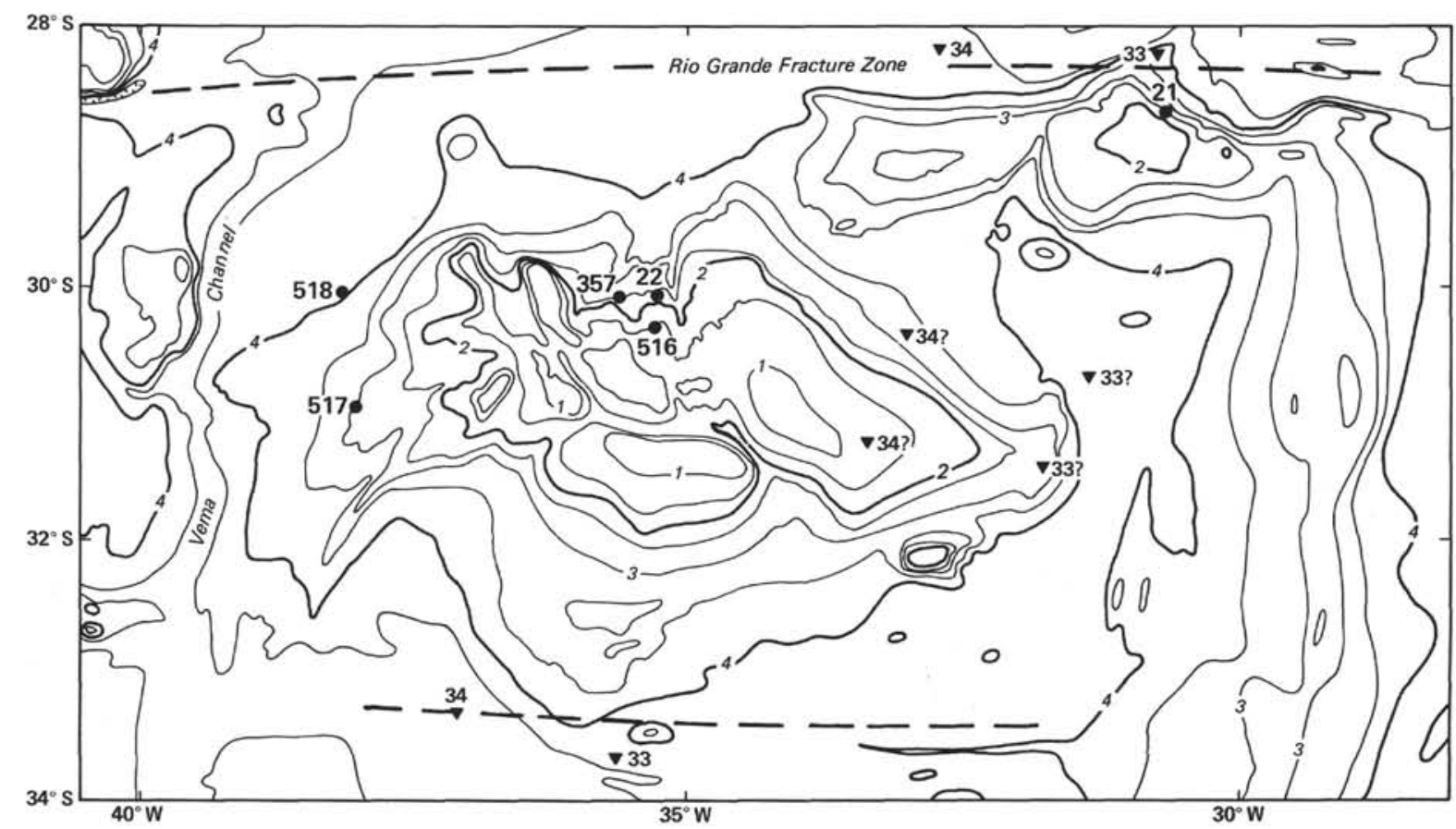

Figure 2. Bathymetry of Rio Grande Rise, contoured at 0.5 -km intervals. Modified from Barker and others (this volume) to show magnetic anomalies (solid triangles), and location of graben (thick dashed line) across crest of Rise.

not knowing whether a small fracture zone, required to accommodate the discrepant strike of a line joining the identified anomalies, runs north or south of Site 516 . The other part of the uncertainty allows for the possibility that lava from a subaerial ridge crest (see below) might flow some distance from the crest itself $(10 \mathrm{~km}$ east-west is equivalent to $0.27 \mathrm{Ma}$ ). A probably larger but unquantifiable uncertainty, however, resides at present in the true age of Anomaly 34 (see, for example, Ness et al., 1980; Lowrie and Alvarez, 1981; Berggren et al., this volume).

Thus, within their several uncertainties, the radiometric, biostratigraphic, and magnetostratigraphic estimates of the age of the basalt at the bottom of Hole $516 \mathrm{~F}$ coincide with the age of the ridge crest at Site 516, deduced from regional tectonic data. This coincidence and the geochemical nature of the basalt suggest strongly that it was produced at the Mid-Atlantic Ridge crest. We need to consider next if this conclusion is true of all of the main body of the Rio Grande Rise and if it can provide a paleodepth datum for use in computing a subsidence history.

Sediments directly overlying the lavas at Site 516, and filling the uppermost part of veins within the lavas (Core $516 \mathrm{~F}-126$ ), indicate a water depth of possibly less than $20 \mathrm{~m}$ (Milliman, this volume). Overlying sediments contain deeper water indicators; Section $516 \mathrm{~F}-124-2$ is assigned a $100-150 \mathrm{~m}$ depth of deposition, but Milliman's estimate of $1000-2000 \mathrm{~m}$ for Core $516 \mathrm{~F}-123$ conflicts with a shoaler estimate (100-500 m) by Dailey (this volume), based on benthic foraminifers. Nevertheless, the general indication is that rapid subsidence from very close to sea level followed the eruption of the uppermost lava. Also, the terrigenous component of the Creta- ceous sediments at both Site 516 and Site 357 (Supko, Perch-Nielsen, et al., 1977) decreases upward, which may (though not necessarily) reflect the decreasing influence, through erosion and subsidence, of local subaerial topographic highs.

Multichannel seismic reflection profiles, which were obtained by the University of Texas Marine Science Institute (UTMSI) during site surveys around Site 516 (Barker et al., this volume), show a sequence of planar dipping reflectors beneath the reflector associated with the basalt at the base of Hole 516F. These are correlated with the dipping reflector sequences now being mapped along many continental margins (Hinz, 1981; Hinz and Krause, 1982; Mutter et al., 1982) and found where sampled to be subaerial or shallow submarine lavas with interbedded shallow marine or alluvial sediments (Talwani, Udintsev, et al., 1976; Roberts et al., 1982). The sequence at the margins appears to be a subaerial or near-sea-level extensional (mid-ocean ridge) facies association, with laterally extensive subaerial basalts and interbedded sediments providing the lateral continuity of impedance contrast that produces the reflectors and that a deep-water pillow lava section lacks. It is not necessarily confined to continental margins; Icelandic plateau basalts, submerged, would show similar characteristics.

The dipping reflector sequence may be correlated with the $3.6-\mathrm{km} / \mathrm{s}$ layer found on two sonobuoy seismic refraction lines on the Rise (McDowell et al., 1977) and seen on other aseismic ridges in the South Atlantic (Houtz et al., 1977; Kumar, 1979). The sequence is found elsewhere beneath the shallow part of the Rio Grande Rise (Barker et al., this volume), although the sparse and uneven nature of the multichannel seismic cover precludes a complete assessment. The ridge crest 
origin inferred for basement at Site 516 seems applicable on this criterion to the entire main body of the Rise.

The dipping reflector sequence is not seen in the very shallowest part of the Rio Grande Rise, which is occupied by a series of guyots separated by a sinuous graben oriented WNW-ESE (Barker et al., this volume, and Fig. 2). The origin of this crestal morphology is considered next.

\section{Mid-Eocene Volcaniclastics}

Like almost all of the remainder of the sedimentary section at Site 516, most of the middle Eocene Unit 4 was deposited as a pelagic nannofossil and foraminiferal ooze. Uniquely, however, (apart from a very thin sequence directly overlying basement) Unit 4 also contains partly volcaniclastic glauconite-rich turbidites, slide debris, and thin altered volcanic ash beds. The base of the unit is a 15 -m-thick slide, largely composed of lower Maestrichtian limestone showing soft-sediment deformation. The abundance of turbidites and ash beds and the noncarbonate content decrease upward within the unit. Some turbidites contain contemporaneous reefal debris (Tjalsma, this volume), indicating shallow water upslope.

Several of the presumed ash beds have been studied in detail by Bryan and Duncan (this volume), who note a distinct upward change in their character. The older beds may well be airfall ash or possibly fine-grained turbidites produced by erosion and redeposition of an ash soon after its eruption. They contain fine-grained lithic fragments and fresh dark euhedral biotite, in a clay matrix that could be altered volcanic glass. Biotite from one such bed gave a good K-Ar date of $47.4 \pm 0.7 \mathrm{Ma}$, the same age as the surrounding pelagic carbonates. The biotite is potassic and has affinities with the alkalic volcanics dredged from the Rio Grande Rise and described by Fodor, Husler, and Kumar (1977). The younger "ash" beds contain coarser, rounded clasts and abundant quartz; Bryan and Duncan (this volume) believe that they were caused by subaerial erosion of a mixed volcanic and plutonic terrane. Thus, active volcanism appears to have been confined to the early middle Eocene.

Carbonates within Unit 4 are more compacted and diagenetically altered than those above and below; they have higher densities and compressional-wave velocities and lower porosities. The unit appears both thicker and longer lived than its equivalent, the middle Eocene "volcanic breccia" at Site 357 downslope (Fodor and Thiede, 1977), although the lack of continuous coring at the earlier site hinders comparison. This contrast is verified by the evidence of seismic reflection profiles around Site 516 (Barker et al., this volume). Unit 4 is unambiguously identified with a seismic sequence whose variable thickness and abundance of short, discordant internal reflectors distinguish it from all others in the section (Fig. 3). The rough topography of the top of this sequence caused it to be mistaken for igneous basement on the older, single-channel profiles used in the original selection of Site 516 (e.g., Fig. 11 of Barker et al., this volume). Concern about possible hydrocarbon reservoir properties of this "midsection dome" sequence, when newer UTMSI multichannel seismic profiles revealed its position and character, caused drilling to be confined to the lower flanks of one of the least well-developed of the domes. Nevertheless, the reflection profiles provide reasonably convincing evidence of its nature and origin. The sequence thins downslope from Site 516, away from the crest of the Rise, and the dome topography disappears. It is thickest beneath the base of the steep slope leading up to one of the crestal guyots (Fig. 3). The guyot itself is underlain by northeast-dipping sedimentary sequences, all but the youngest of which are truncated at or very close to its flat top. Acoustic basement is exposed at the seabed at the southern end of the guyot shown in Figure 3. The guyot's steep southern slope is one side of a graben filled with rotated fault blocks and oriented WNW-ESE along the crest of the Rise. About $50 \mathrm{~km}$ west of where it is crossed in Figure 3, this same scarp slope yielded alkalic lavas from two near-coincident dredge stations (Fodor, Husler, and Kumar 1977; Thompson et al., this volume).

The guyot is interpreted as a tilted, uplifted block (Barker et al., this volume). The tilting caused the sedimentary slides such as that forming the base of Unit 4 . The greater thickness of the "midsection dome" sequence nearer the guyot, its chaotic acoustic character and the domes themselves are controlled by the distribution of slumped debris. At the root of the domes may be larger, coherent slump blocks from deeper in the original section or an accumulation of smaller slides. Dome reflector topography propagated upward by faulting caused by differential compaction and diagenesis. Subaerial erosion of the uplifted and tilted guyot planed its top and provided the partly volcanogenic turbidites within Unit 4 . The change in character of the "ash" beds within Unit 4 results from progressively deepening erosion levels on the crest of the Rise. Barker and others (this volume) also think that the graben was formed after the initial uplift and tilting, because the rotated fault blocks within it are devoid of prefaulting sedimentary cover, suggesting that they too suffered subaerial erosion.

\section{Discussion}

The accumulated evidence points strongly towards a middle Eocene episode of volcanism and tectonic disturbance on the Rio Grande Rise. Some features, of course, do have alternative explanations: Eocene volcanism was widespread in the South Atlantic (Zimmerman, this volume), and volcanic ash can travel thousands of kilometers in large amounts (e.g., Ninkovich et al., 1978). There would probably be other alkalic sources in Brazil (Campos et al., 1974) or on the southwestern Walvis Ridge nearer to the ridge crest (similar to Site 359, Supko, Perch-Nielsen, et al., 1977). Also, alkalic volcanism is not necessarily off-axis, as shown by its coexistence with tholeiitic activity at the obliquely extensional Africa-Eurasia plate boundary in the Azores (Ridley et al., 1974; Searle, 1980). The alkalic rocks dredged from the Rise and other places in the Rio 


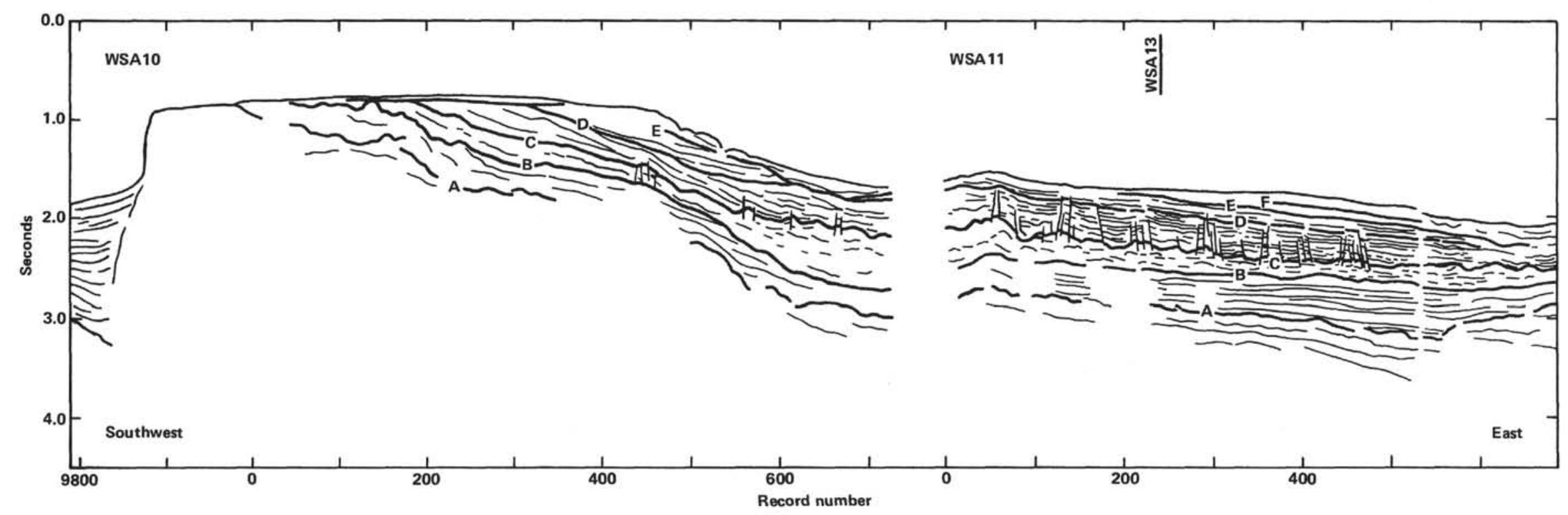

Figure 3. Reflection profile across graben, guyot, and shoulder on northern flank of Rio Grande Rise, close to Site 516 (from Barker et al., this volume). "Dipping reflector" sequence lies beneath Reflector A, and sequence identified with partly volcaniclastic middle Eocene Unit 4 lies between Reflectors B and C. 
Grande Rise-Walvis Ridge province could have been produced close to the ridge crest, as many have suggested hitherto (see Barker and Carlson, this volume).

Nevertheless, the sharp coincidence in the early middle Eocene of fresh alkalic ash and the differential uplift that destabilized considerable thicknesses of sediment on the crest of the Rise to produce slides (such as that at the base of Unit 4 at Site 516) is convincing evidence of a local volcano-tectonic event. The contribution of this short event to the present bulk of the Rise is more difficult to judge, as is the relative importance within it of volcanism and tectonic activity. The contribution of volcanism appears limited; the volcanogenic component of Unit 4 does not exceed $20 \%$ (of $240 \mathrm{~m}$ ) at Site 516. It is only partly the direct result of a short volcanic episode in the early middle Eocene; otherwise it is the product of subsequent subaerial erosion of the volcano and its root, and probably also of original Late Cretaceous ocean floor. The seismic sequence corresponding to Unit 4 is of only limited extent on the northern shoulder of the Rise and even less well developed on the southwestern flank. The only one of the crestal guyots to have been examined in any detail is a tilted oceanic section, rather than a volcano. The extent of slide debris and the nature of other guyots will not be known without better multichannel seismic coverage and more sample sites, but if our present data are typical, then volcanism would appear to be minor and, like differential uplift, confined largely to the crest of the Rise. The main bulk of the Rio Grande Rise undoubtedly owes its anomalous elevation to its original formation at a subaerial section of the mid-ocean ridge in the Late Cretaceous.

\section{REGIONAL TECTONIC EVOLUTION}

The close coincidence between the $84.5 \mathrm{Ma}$ age for the ridge crest at Site 516 from regional magnetic anomalies, the $86 \mathrm{Ma}$ radiometric date for the basalts at the base of Hole $516 \mathrm{~F}$, and the (rather less precise) magnetostratigraphic and biostratigraphic ages strongly suggests that those basalts were formed at the midocean ridge crest. This conclusion is supported by the basalt geochemistry and by the paleoecologic evidence of rapid subsidence after eruption ceased. The very shallow paleodepths of the basal sediments are consistent with conclusions drawn from multichannel seismic reflection profiles around Site 516: much of the main body of the Rio Grande Rise was formed by "subaerial seafloor spreading"' at a divergent plate margin near sea level.

The other contribution of drilling at Site 516 is the firm establishment of a short off-axis volcano-tectonic disturbance involving uplift, tilting and faulting, and alkalic volcanism in the early middle Eocene. The great extent of the graben across the Rise and the similar least depths of the many flat-topped guyots suggest that this was a unique event in the evolution of the Rise. The Maestrichtian $\mathrm{Rb}-\mathrm{Sr}$ age for secondary hydrothermal mineralization within the basal lavas in Hole 516F (Hart and Staudigel, this volume) probably does not have a comparable tectonic significance.
Before attempting to build a subsidence curve for the Rio Grande Rise from these data, we need to assess their contribution towards understanding the tectonic evolution of this part of the South Atlantic, in which the relative importance of hot-spot plumes, leaky transforms, ridge jumps, and off-axis volcanism has been the subject of much debate.

The mid-ocean ridge in this part of the South Atlantic is not centrally located between the continental margins (e.g., Mascle and Phillips, 1972; Sclater and McKenzie, 1973). Evidently, the ridge jumped eastward before Anomaly 34 time (Ladd, 1974), and the asymmetric disposition of continental margin salt provinces, which in the south favors the Brazilian above the Angolan margin, has been attributed to an eastward ridge jump at the end of the Aptian (Leyden et al., 1976; Ponte and Asmus, 1976; Cande and Rabinowitz, 1978, 1979; Kumar and Gamboa, 1979). The southern boundary of this jump was the Rio Grande Fracture Zone (Fig. 1), which forms the northern boundary of the Rio Grande Rise (Gamboa and Rabinowitz, 1981). This fracture zone is continuous with the São Paulo Ridge, the southern boundary of the São Paulo Plateau. The asymmetric position of the ridge crest extends farther south, however, and Kumar (1979) has proposed a separate eastward jump, within this southern region, later than the first (at $100 \mathrm{Ma}$ rather than $106 \mathrm{Ma}$ ). He suggested that this second jump (to a location near the Vema Channel, $\sim 39.5^{\circ} \mathrm{W}$ ) occurred shortly before the start of the anomalous volcanism that produced the Rio Grande Rise and that it extended as far south as a fracture zone at $33.5^{\circ} \mathrm{S}$, which offsets magnetic anomalies (Cande and Rabinowitz 1979) but has little topographic expression (Fig. 1). This notion is inherently plausible; the African Mesozoic magnetic anomalies north of the Frio Ridge were transferred westward to the São Paulo Plateau (Cande and Rabinowitz, 1978, 1979), but remained on the African plate farther south (Rabinowitz, 1976), showing that the jump there was later than in the north. The nature of the jump, however, may not have been exactly as Kumar supposed. There is now good evidence (e.g., Barker, 1979; LaBrecque and Hayes, 1979) that the destinations of ridge crest jumps are often marked by anomalously elevated ocean floor, typically rough, strongly magnetized, and by implication largely volcanic. In contrast, the abandoned ridge crests usually leave little trace. Therefore, the more likely destination for the eastward ridge crest jump was the present western (older) end of the Rio Grande Rise, near $37^{\circ} \mathrm{W}$, rather than the Vema Channel at $39.5^{\circ} \mathrm{W}$ (Fig. 2). Thus, the anomalous elevation of the Rio Grande Rise was probably initiated by excess volcanism associated with the process of rifting the existing oceanic lithosphere. The similarity between this process and off-axis volcanism is considered further below.

If just one jump occurred in this southern section, to $37^{\circ} \mathrm{W}$, then Rabinowitz and LaBrecque's (1979) poles and rates of South Atlantic opening give an age of about $91 \mathrm{Ma}$ (early Turonian) for the jump. Subsequently, the main body of the Rio Grande Rise would have formed 
on the South American flank of the new elevated spreading center, and the oldest, most easterly northsouth component of the Walvis Ridge (near $24^{\circ} \mathrm{S}, 7^{\circ} \mathrm{E}$; Area A in Fig. 1) on the African flank. This part of the Walvis Ridge appears slightly smaller than the main elevated body of the Rio Grande Rise; so, some kind of minor adjustments, involving additional small eastward jumps of the ridge crest, may have followed shortly after the main jump, in which case the 91 Ma estimate is a maximum age.

Others of the more massive north-south elongations of the Rio Grande-Walvis system may have had a similar origin at eastward ridge jumps, and the intervening east-west fracture zone sections, similarly elevated, were probably in some way associated. We can trace a general southward progression, from the initial continental alkalic volcanism of the Kaoko and Serra Geral basalts, which predated South Atlantic opening (Siedner and Miller, 1968; Gidskehaug et al., 1975; Campos et al., 1974). Both the São Paulo Ridge and the Frio Ridge (Fig. 1) have a fracture zone orientation (the same fracture zone: Kumar 1979); they formed a continuous, probably subaerial elevation during the earliest stages of South Atlantic opening, before the first ridge jump at $106 \mathrm{Ma}$. The second jump (at $91 \mathrm{Ma}$ ) may have been encouraged by continued volcanism on the Frio Ridge, which is topographically continuous with the elevation complementing the main Rio Grande Rise (Area A in Fig. 1). Continuing the southward succession, Richardson and others (1982) report that the next ridge crest section of the Walvis Ridge (centered on $29^{\circ} \mathrm{S}, 3^{\circ} \mathrm{E}$ : Area B in Fig. 1) may have been produced after a ridge crest jump about $71 \mathrm{Ma}$. This region was the site of Leg 74 drilling (Moore, Rabinowitz, et al., 1983). The relationship between this part of the Walvis Ridge and the eastern, north-south ridge of the Rio Grande Rise (C in Fig. 1) is unclear. In a reconstruction, these elevations partly overlap, but the Rio Grande Rise ridge extends farther to the north, and magnetic anomalies there appear not to connect it with a ridge crest jump. Possibly its northern part, which is about the same age as the jump, was some kind of aulacogenic northern extension of the destination of this third jump.

Ridge B (Fig. 1) is the most southwesterly of the massive, elongated components of the Walvis Ridge; farther to the southwest the Walvis Ridge becomes a series of isolated seamounts, culminating in the presently active Tristan da Cunha and Gough Island groups. These latter lie about $400 \mathrm{~km}$ away from the mid-ocean ridge crest, on ocean floor about $20 \mathrm{Ma}$ old. Their associated hotspot swell is illustrated by the abnormally large distance from the ridge crest of the 4000 -m depth contour (Fig. 1). On the South American plate, the hot-spot swell is absent and the equivalent of the southwestern, seamount province of the Walvis Ridge is very poorly developed.

In the contrasting morphologies of the older and younger provinces lies the key to an understanding of their origins. Presumably, like Tristan da Cunha and the seamount sampled at Site 359 (Supko, Perch-Nielsen, et al., 1977; Barker and Carlson, this volume), all of the isolated seamounts of the southwestern Walvis Ridge were formed above an off-axis hot spot on the African plate. I suggest that the older, more massive bodies now formed on both plates probably started in the same way, but that the hot spot was sufficiently vigorous to "capture" the mid-ocean ridge crest and penetrate the thin lithosphere of active or newly extinct transform faults. Conversely, the younger seamounts may be seen as failed ridge jumps and sporadic, wouldbe exploiters of fracture zone fabric.

Thus, I posit a primary Serra Gerral-Kaoko hot spot, a sublithospheric inhomogeneity, fixed in the mantle in the sense of Wilson (1965). First, this contributed to the breakup of West Gondwanaland (see below), then continued its activity as the South Atlantic opened, and as South America and Africa slowly moved (northwest and northeast, respectively) away from it. The South American plate appears to have had a slightly greater westward component of motion, so that the ridge crest migrated westward away from the hot spot. Hot spot volcanism thus became off axis, as it is now. Initially, however, during the Cretaceous, the hot spot was able to cause eastward jumps of the ridge crest, turning an initial off-axis (alkalic ?) volcanism into a particularly elevated variety of (tholeiitic ?) ridge crest volcanism. During the Cenozoic, ridge crest capture became impossible and the hot spot volcanism remained isolated, off axis, and alkalic, as now. This also explains why no real equivalent of the southwestern, seamount province of the Walvis Ridge is found on the South American plate.

\section{Swell Push Forces}

The key to the process of ridge capture lies in distortion of the ambient stress field in the lithosphere flanking the ridge crest by the anomalous hot spot elevation-the local reversal of the "ridge push" force (Watts et al., 1980; Dahlen, 1981). The ridge push force may be seen as the component of the weight of the elevated oceanic lithosphere near spreading centers that acts perpendicular to the ridge crest and parallel to the inclined base of the lithosphere and that causes the young lithosphere to slide downslope away from the ridge crest. It is one of the two significant driving forces of plate motion. For normal oceanic lithosphere, with elevation proportional to the square root of age, the ridge push force increases linearly with the age of the lithosphere (Dahlen, 1981). Because of the anomalous elevation of a hot spot swell, there will be a similar force acting radially outward around it. If this "swell push" force (Fig. 4A) becomes sufficiently great in an area near a short section of ridge crest, because of the cumulatively greater elevation of the lithosphere on the swell, then the ridge push force may be overcome. Along a line of swells, or of local areas of uplift and thinning within one swell (i.e., volcanoes), the swell push forces will reinforce in a direction perpendicular to that line, mimicking the linearity of the ridge push force. If the lithosphere on the swell is sufficiently weak to be torn by the swell push force, then the spreading center may jump to the center of the swell and further spreading at the original ridge crest may be prevented. I suggest that this happened three 

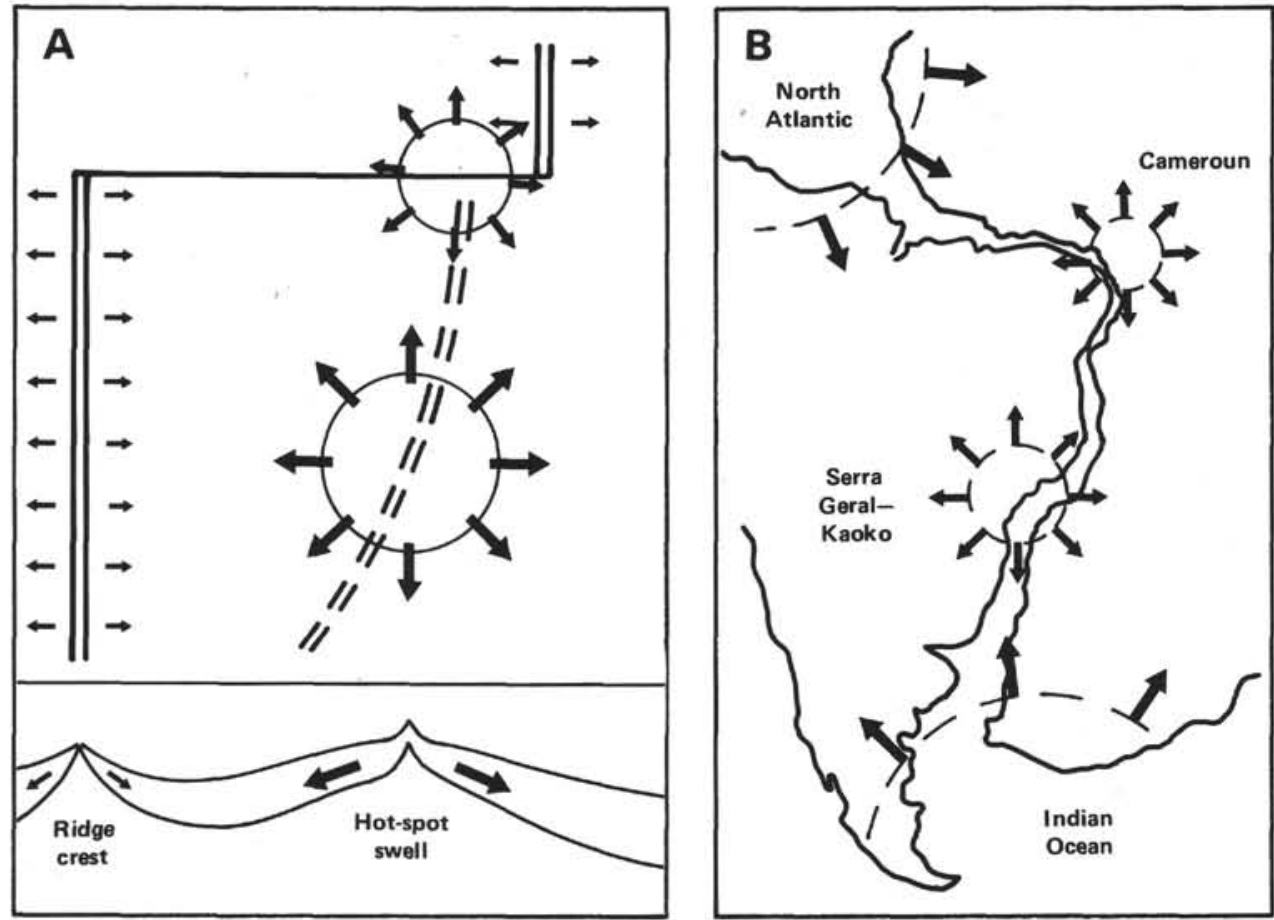

Figure 4. A. Schematic model of hot spot-related eastward ridge jump. New ridge (dashed double line) forms when ridge push force (short arrows) is overcome over restricted region by analogous "swell push force" (long arrows). Line of new ridge is influenced by location of thinned, weakened lithosphere on hot-spot swell. Such a jump $91 \mathrm{Ma}$ ago started formation of Rio Grande Rise. B. similar combination of thinned, weakened lithosphere and outward forces from uplifted swells suggested as responsible for initial rifting of South Atlantic in Early Cretaceous. Diagram shows Serra GeralKaoko (Tristan) and Cameroun (St. Helena) hot spots, and elevations associated with young North Atlantic and proto-Indian oceans.

times within the Walvis Ridge-Rio Grande Rise system, at 106,91 , and $71 \mathrm{Ma}$, but has not happened since.

This interpretation has several interesting consequences. First, Crough's (1978) thermal rejuvenation model for hot-spot swells predicts a swell elevation $(4250 \mathrm{~m})$ that seems inadequate for ridge crest capture as suggested here. Indeed, the region around Tristan da Cunha at present is more elevated than $4250 \mathrm{~m}$, even though no capture has occurred within the Cenozoic. Some additional mechanism for elevation of hot-spot swells is required, related to the composition within lithosphere or underlying mantle, an anomalous sublithospheric thermal structure, or the dynamics of mantle convection (McKenzie et al., 1980). Secondly, ridge capture is more likely within ocean floor produced by faster spreading, for two reasons. In the South Atlantic context, we suppose the ridge crest to migrate slowly westward off a swell of constant diameter, so that the margins of the swell are "seen" by the stress field (i.e., the swell becomes recognizably off axis) at about the same distance from the ridge crest whatever the spreading rate. For faster spreading, (1) the oceanic lithosphere beneath the swell will be younger, therefore thinner and potentially weaker, and (2) the ridge push force, a linear function of lithospheric age, will be smaller and more easily overcome. Thus, the faster the spreading rate, the more likely is the ridge jump process, a matter of "tearing along the perforations," to succeed. This relationship, apart from any considerations of changing hot-spot vigor, could explain why ridge crest capture was successful in the Cretaceous, during and shortly after the Cretaceous normal polarity interval, but unsuccessful in the Cenozoic, when all the off-axis lithosphere was being produced at only two-thirds of the previous rate (Rabinowitz and LaBrecque, 1979; Barker and Carlson, this volume, Table 1).

The fracture zone orientations of some of the ridges in the older parts of the Walvis Ridge and Rio Grande Rise and the linearity of some younger seamount chains provide evidence that fracture zones constitute a weakness within the fabric of oceanic lithosphere, which hotspot volcanism may preferentially exploit. Such exploitation may aid the process of ridge crest capture, both by thinning and weakening the adjacent lithosphere and by producing additional uplift, which locally increases the swell push force (Fig. 4A). There is no evidence, however, from Leg 72 or from other studies in the region, that fracture zones also form conduits for shallow horizontal magma flow (Vogt and Johnson, 1975).

The Serra Geral-Kaoko volcanic province (Fig. 4B), the earliest manifestation of the present Tristan hot spot, apparently predates the start of South Atlantic opening (e.g., Campos et al., 1974). The present St. Helena hot spot (Black and Girod, 1970) is also probably at least as old. It is therefore pertinent to ask if, through a similar mechanism of lithospheric thinning and uplift-induced stress, the hot spots could have caused or at least influenced the rupture of West Gond- 
wanaland (Fig. 4B). Uplift and lithospheric thinning would also have been associated with active spreading in the North Atlantic and Indian oceans in the Earliest Cretaceous. Computation of the stresses necessary to rift continental lithosphere in this way is beyond the scope of this discussion, but the role of hot spots in initiating continental rifting in this way does not appear to have been considered previously.

\section{Middle Eocene Activity}

Middle Eocene volcanism on the Rio Grande Rise is difficult to understand in terms of the migration of the South American plate with respect to a single well-defined mantle inhomogeneity (hot spot) now centered on Tristan da Cunha. In the early middle Eocene, the Rise was about $900 \mathrm{~km}$ west of the ridge crest, and the center of the Serra Geral-Kaoko hot spot lay probably even farther away, on the African plate and farther south. The renewed burst of alkalic volcanism in Brazil (80-50 Ma; Campos et al., 1974) is similarly incongruous and may be related. For off-axis volcanism in general, however, these occurrences are not so strange. For example, the Cape Verde Islands have experienced several episodes of midplate volcanic activity since the mid-Cretaceous, on original ocean floor of Latest Jurassic or Earliest Cretaceous age (Stillman et al., 1982). The hot spot-related origin of the Rise and similar areas may make them more vulnerable than normal oceanic lithosphere to magmatic penetration as they subsequently pass over other mantle inhomogeneities. This vulnerability could stem from either an anomalous lithospheric composition beneath the Rise or anomalous topography on its base, possibilities that are considered in the following discussion of a subsidence curve for the Rio Grande Rise. In view of the time sequences and relative positions of the Cenozoic Brazilian and Rio Grande Rise midplate activity, the South American plate may have passed over the same mantle inhomogeneity, northwest of and distinct from the Tristan hot spot but similarly fixed in the mantle.

\section{Rio Grande-Walvis Geochemistry}

I have suggested how the contrasting morphologies of different parts of the Rio Grande-Walvis system reflect the different ways in which a zone of anomalously hot, light, or volatile-rich sublithospheric mantle has interacted with the ridge crest-fracture zone fabric of oceanic lithosphere. The chemistry of the rocks produced should also reflect that range of interactions. Because all of the Rio Grande-Walvis volcanism is hot spot related, whether occurring at the ridge crest, along transform faults, or off axis, all of its products should be distinct from depleted normal (N-type) MORB. Further, one might expect enriched (E-type) or T-type MORB on the more massive ridge crest bodies and more enriched, alkalic rocks at the isolated off-axis volcanoes. The nature of transform fault volcanism is uncertain and may show both alkalic and tholeiitic components. Alkalic rocks are also predicted to occur at deeper levels on the older flanks of the more massive, ridge crest bodies, be- cause initial activity there, before ridge crest capture, was essentially off axis.

Few volcanic rocks from the Rio Grande-Walvis Ridge system have been analyzed chemically, even including those from Leg 72 (Thompson et al., this volume; Weaver et al., this volume) and Leg 74 (Richardson et al., 1982). Tholeiitic rocks from the eastern Walvis Ridge (Hekinian, 1972; Humphris and Thomson, 1982), the central Walvis Ridge (Richardson et al., 1982), the mid-ocean ridge crest near Tristan da Cunha (Schilling et al., 1981), and Site 516 basement (Thompson et al., this volume; Weaver et al., this volume) are all E-type or T-type MORB, enriched in LREE. Alkalic rocks broadly similar to those from Tristan da Cunha have been found on another isolated seamount of the southwestern Walvis Ridge, sampled at Site 359 (Fodor, Keil, et al., 1977); on the Rio Grande Rise crest (Fodor, Husler, and Keil, 1977; Bryan and Duncan, this volume); in a conglomerate on the São Paulo Ridge at Site 356 (Fodor, Husler, and Kumar, 1977); and in company with tholeiitic rocks on the eastern Walvis Ridge (Hekinian, 1972; Humphris and Thompson, 1982); none of these sites, however, yielded really fresh rocks. The first two areas are off axis (middle Eocene Rio Grande Rise crest), and the second two have a transform fault orientation. Thus, the chemistry of all available samples is broadly consistent with the tectonic model but does not provide a very stringent test of the model.

One interesting result is Richardson and others' (1982) model for the source of central Walvis Ridge basalts, erupted shortly after the $71 \mathrm{Ma}$ ridge jump (Area $B$ in Fig. 1). They found that even a two-component variably veined mantle source (e.g., Wood, 1979; Tarney et al., 1980) was inadequate to explain all of the variation in the basalts; they also concluded, however, that the source of N-type MORB was not a significant component of the system required (three or more components). The process of hot spot-induced ridge crest capture might explain these characteristics. One or more components would be derived from partial melting, at the ridge jump destination, of the existing oceanic lithosphere, itself heterogeneous and probably E-type or T-type if created originally within the hot spot swell. Additional components would come from the mantle beneath the lithosphere at the ridge jump destination, from the same hot-spot plume perhaps but after a pause of up to $20 \mathrm{~m} . y$., during which time the plume could have evolved. Thompson and others (this volume) suggest that the hot spot has changed with time.

\section{SUBSIDENCE HISTORY OF THE RIO GRANDE RISE}

The reconstruction of the subsidence history of the Rio Grande Rise requires:

1) a thermal isostatic subsidence model, similar if not identical to that for normal oceanic lithosphere but including the effects of off-axis volcanism and a subaerial rather than a submarine origin;

2) a model for the isostatic effects of sedimentation and erosion, including an assessment of the regionality 
of the isostatic response resulting from lithospheric stiffness;

3) a model for sediment compaction under load;

4) an estimate of eustatic changes of sea level since the mid-Cretaceous.

Because of the new information from Leg 72, this subsidence model is likely to be quite different from that of Thiede (1977), which is currently widely accepted and used (see Barker and Carlson, this volume). Thiede concluded that the Rio Grande Rise formed at or near the mid-ocean ridge crest in the Late Cretaceous (97-95 Ma) as an oceanic island or island group reaching $2000 \mathrm{~m}$ or more above sea level; it then subsided as a single unit without interruption, essentially as would normal ocean floor. Drilling at Site 516 produced more precise data, including a well-defined basement age and paleodepth. Leg 72 has also provided firm evidence of a middle Eocene volcano-tectonic event, which not only would have perturbed a normal oceanic thermal subsidence curve but also would have included faulting and tilting; this throws doubt on the validity of combining paleodepth data from different areas on the assumption that the entire Rise behaved rigidly throughout. In addition, since Thiede's work, there have been developments in the understanding of sediment compaction and the history of eustatic sea level change. Finally, because of the dominant importance of the new data, I adopt here a different approach from that of Thiede; I construct a subsidence curve based on Leg 72 data and tectonic inference alone, then compare it with the paleontologic depth estimates as an independent data set.

\section{Oceanic Thermal Isostatic Subsidence}

The general validity for the oceans of a seabed subsidence curve proportional to the square root of age has been demonstrated empirically (Sclater et al., 1971; Trehu, 1975; Parsons and Sclater, 1977) and is justified theoretically in terms of a thermal boundary layer model of oceanic lithosphere (e.g., Parker and Oldenburg, 1973; Davis and Lister, 1974). Of the estimated coefficients-for example, depth $h_{t}$ (in m) at time $t$ (in Ma): $h_{t}=2530+336 t^{1 / 2} \mathrm{~m}$ (Trehu, 1975)-only the age-dependent term is constrained by the physical properties of the lithospheric model. The similarity of ridge crest depths $\left(h_{\mathrm{o}}\right)$ in different oceans presumably reflects a generally similar composition and thermal structure and an interconnection of the sublithospheric mantle.

Heestand and Crough (1981) have argued that the data used in computations like Trehu's (1975) are contaminated by depths from midplate hot-spot swells, where the ocean floor has been reheated or modified compositionally, and thus elevated to a depth no longer representative of its original age. Using only "uncontaminated" data from the North Atlantic, Heestand and Crough (1981) obtain a relationship $h_{t}=2700+$ $295 t^{1 / 2} \mathrm{~m}$. Their analysis also produces a fairly constant value, $368 t^{1 / 2}$, for the coefficient of the age-dependent term for their three near zones, inside an $800-\mathrm{km}$ radius from a hot-spot track. It is difficult to appreciate what physical reality this coefficient has, however, because crossing a hot-spot swell may reset the age; yet no dis- tinction is made in their analysis between proximity of a data point to a hot spot at present and proximity in the past. Ocean floor moving off a hot-spot swell will perhaps subside more rapidly, and ocean floor approaching a swell subside less rapidly, than ocean floor that has always been remote from these features, but why this effect should bias the data (if it does) towards more rapid subsidence is uncertain. The Rio Grande Rise was formed initially on a hot spot and encountered another in the middle Eocene, so it is unavoidably "contaminated." It has probably never been more than about $1200 \mathrm{~km}$ from a hot spot. I use Heestand and Crough's proximal coefficient $368 t^{1 / 2} \mathrm{~m}$ here in computing its thermal subsidence, but also show the effects of the distal coefficient $295 t^{1 / 2} \mathrm{~m}$ as a limiting case.

\section{Subaerial Subsidence}

A typical oceanic subsidence model might be inappropriate for the Rio Grande Rise in other ways. For example, the isostatic balance underlying the model is different if the lithosphere is subaerial at the ridge crest, as in Iceland (Figs. 5A-B). The oceanic lithosphere subsides as it cools, because it is denser than the asthenosphere beneath. If the base of the lithosphere is an isotherm (as the $t^{1 / 2}$ dependence implies) and if variation of physical properties with depth and radioactive heating within it are neglected (common simplifications-e.g., Crough and Thompson, 1976), then the lithospheric temperature distribution gives rise to a mean density unchanging with age. Using $368 t^{1 / 2} \mathrm{~m}$, Parker and Oldenburg's (1973) lithospheric thickness $Z_{t}=9.4 t^{1 / 2} \mathrm{~km}$, and an asthenospheric density $\left(\varrho_{A}\right)$ of $3.3 \mathrm{~g} / \mathrm{cm}^{3}$, in their submarine isostatic subsidence expression $h_{t}-h_{\mathrm{o}}=Z_{t}$ $\left(\varrho_{L}-\varrho_{A}\right) /\left(\varrho_{A}-\varrho_{W}\right)$, the lithospheric density $\varrho_{L}$ becomes $3.389 \mathrm{~g} / \mathrm{cm}^{3}$ (Fig. 5A). If the oceanic lithosphere is subaerial (Fig. 5B), the isostatic expression relating subsidence and lithospheric thickness becomes $h_{t}-h_{\mathrm{o}}$ $=Z_{t}\left(\varrho_{\mathrm{L}}-\varrho_{\mathrm{A}}\right) / \varrho_{\mathrm{A}}$, which for the same density contrast provides a subsidence coefficient of only $254 t^{1 / 2}$. Areas partly submerged but with a rigid lithospheric response give intermediate values. This difference between subaerial and submarine subsidence rates is independent of any chemical or thermal differences between the mantle beneath normal ocean floor and that beneath hot-spot swells. The different subsidence rates exaggerate existing topographic differences between subaerial and submarine provinces and are reinforced in this by the isostatic response to the coupled processes of subaerial erosion and marine sedimentation.

The interpretation that seismic reflectors around Site 516 represent a subaerial spreading sequence raises the possibilities that the uppermost lava flowed some distance from the ridge crest, that a long period of subaerial erosion then occurred before the basal marine transgression at the site, and that even then the surrounding areas remained subaerial. These possibilities are difficult to quantify; the lengths of Icelandic lavas away from their fissures average about $10 \mathrm{~km}$ (Bodvarsson and Walker, 1964), equivalent here to about 0.27 m.y. Radiometric and magnetic anomaly ages coincide within experimental error. Biostratigraphic control on 


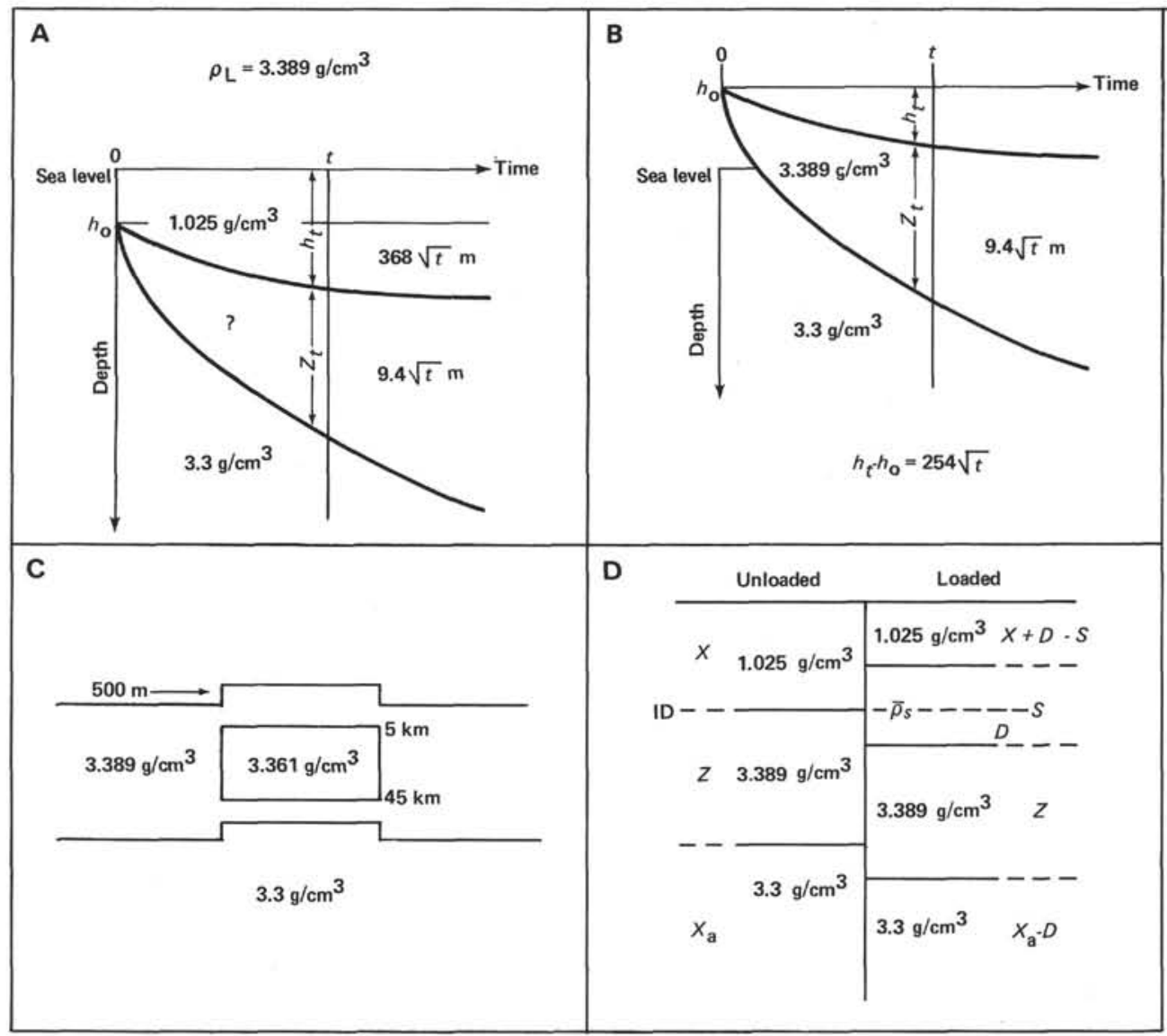

Figure 5. Illustration of isostatic balance equations. A. Thermal subsidence $(h)$ and thickening $(Z)$ of submarine oceanic lithosphere, with time $(t)$. Common assumptions (see text) give mean lithospheric density $3.389 \mathrm{~g} / \mathrm{cm}^{3}$. B. Subaerial version of same model yields reduced subsidence rate of $0.254 t^{1 / 2} \mathrm{~km}$. C. Density reduction of $0.028 \mathrm{~g} / \mathrm{cm}^{3}$ between 5 and $45 \mathrm{~km}$ depth within the lithosphere, resulting from passage over the hot spot, produces $500 \mathrm{~m}$ of permanent uplift (see text). D. Schematic illustration of local isostatic response to sediment loading, used to produce Figure 7. Thickness $S \mathrm{~km}$ of sediment of mean density $\bar{\varrho}_{S}$ produces depression $D \mathrm{~km}$ of the lithosphere: columns balance at sublithospheric depth $X_{\mathrm{a}}$. ID is isostatic datum.

basal sediments is poor, but there is no sign at Site 516 of the thick coarse basal terrigenous deposit expected if the site had sampled a local topographic low or was remote from the ridge crest so that subsidence had slowed (compare, for example, sediment distribution off southwestern Iceland-Egloff and Johnson, 1979). Nor do the reflection profiles around the site indicate substantial topography on the basement reflector, as might be produced by prolonged subaerial erosion. Thus, the Rise near Site 516 was probably subaerial for only a short period. I have assumed that there was a marine transgression at $84.0 \mathrm{Ma}$ ago, $0.5 \mathrm{Ma}$ after eruption at the ridge crest, and that subsidence was entirely subaerial beforehand, entirely submarine afterwards. This history gives an initial height for the lava of $180 \mathrm{~m}$ above sea level and a width of the Rio Grande islands at any one time of about $40 \mathrm{~km}$, although the ridge crest itself is the oceanic region least inclined to closely fit an (age) ${ }^{1 / 2}$ model (e.g., Davis and Lister, 1974).

\section{Middle Eocene Tectonism}

A model for middle Eocene activity on the Rio Grande Rise must be sought in present-day midplate volcanism. Around all such volcanoes are broad areas, typically $1000 \mathrm{~km}$ across, where the ocean floor is elevated above the age-depth curve. If the volcano is large, the distributed isostatic response to its load produces a moatlike depression around it within this swell (see, for example, the discussion by Watts and others, 1980, of the Emperor Seamount). Detrick and Crough (1978) and Crough (1978) have argued that midplate swells are caused by the reheating and consequent thinning of the oceanic lithosphere. Crough (1978), noting that the swells nearly all lie at about $4250 \mathrm{~m}$ depth, whatever their original age, suggests that the ocean floor has been rejuvenated to a thermal age of $25 \mathrm{Ma}$ and shows that several midplate swells in the Pacific have subsided as would 25-Ma-old oceanic lithosphere, as the Pacific plate has moved off the hot spots. The $4250 \mathrm{~m}$ depth is also appropriate for several swells in the Atlantic, although the Cape Verde Rise is shallower. Some problems remain with this model. Crough's conclusion that the lithosphere is reheated essentially from beneath is not easily reconciled with the very rapid rise of the swell in front of the migrating Hawaiian chain (Crough, 1978, fig. 11) or with surface volcanism, both of which 
require penetration of the entire lithosphere in places. Furthermore, areas around volcanoes on ocean floor younger than $25 \mathrm{Ma}$ are abnormally elevated too. The physical reality of the reheating process is undoubtedly more complex than such a model implies. Nevertheless, thermal rejuvenation provides a reasonable approach to a model for the middle Eocene event. Typical swell dimensions exceed those of the main body of the Rio Grande Rise, and the actual volcanic component there seems to have been very small by Hawaiian standards. I therefore assume the entire Rise to have been "rejuvenated" and elevated $48 \mathrm{Ma}$ ago (early middle Eocene) to the depth at which it lay when $25 \mathrm{Ma}$ old (apart from the effects of sedimentation or erosion).

A further problem is evident in the subsidence curve itself (see Fig. 9 later in this chapter) but may be anticipated here. In a thermal rejuvenation model, the elevation is reversible, and the ocean floor may not be elevated above its original ridge crest depth (even if rejuvenated to $0 \mathrm{Ma}$ !). Yet on Maio, Cape Verde Islands, the original ocean floor, represented by variolitic nonvesicular pillow basalts with estimated eruptive depths greater than $1000-1500 \mathrm{~m}$, is exposed well above sea level, uptilted around a core of later alkalic plutons (Stillman et al., 1982). This elevation is excessive, at least partly irreversible, and of local rather than regional extent, at least where exposed. Such uplift must be related to density contrasts at depth that are of compositional rather than thermal origin and, if permanent and locally exaggerated, reside within the lithosphere rather than the asthenosphere. Similar exposures in the Canary Islands (Robertson and Stillman, 1979), and the survival of the Bermudan swell inspite of a 35-Ma interval since the last eruption (Crough, 1978), suggest that irreversible uplift may be quite widespread. The significant difference might be between the Pacific, where Crough's thermal model works well, and the Atlantic. Whereas the fast absolute motion of the Pacific plate $(90 \mathrm{~mm} / \mathrm{yr}$., Chase, 1978) and vigorous Hawaiian volcanism provide little opportunity for processes of differentiation within the ascending magma, the slower African and South American plate motion $(20 \mathrm{~mm} / \mathrm{yr}$.) and comparatively subdued magmatism in the South Atlantic may be more favorable for such processes. Differentiation within the melt would lead to a density reduction where the lithosphere had been penetrated, which would dome lithosphere over an area and by an amount determined by its thickness and strength (i.e., locally and noticeably around volcanic vents, but also more gently within the bounds of the swell). Such elevation may become permanent as the lithosphere afterwards cools. Thus, the tilt of the original oceanic lithosphere survives around the alkalic plutons on Maio, and within the guyot at the crest of the Rio Grande Rise (Fig. 3), as does probably at least some of a more areally extensive but more subdued uplift of compositional rather than thermal origin. Figure 5C illustrates the crude calculation that a density change of only $0.028 \mathrm{~g} / \mathrm{cm}^{3}$, "frozen" into the lithosphere between 5 and $45 \mathrm{~km}$ depth after passage across a hot spot, would give rise to a permanent elevation of $500 \mathrm{~m}$ compared to unmodified lithosphere of the same thickness.
This density change is only one-third of the lithosphericasthenospheric density contrast computed earlier.

\section{Sediment Compaction History}

Considering the biostratigraphic control and the number and quality of shipboard measurements of wet-bulk density and porosity available for Site 516 , we can estimate the sediment load on the lithosphere for a time in the past and then calculate the resulting isostatic depression (Fig. 5D). To find the paleodepth of the seabed, however, for comparison with paleoecologic estimates, we need also to know the sediment thickness at any given time in the past and thus the compaction history. This problem has long been neglected in paleoceanography (the sediment density is usually assumed to be constant), but it is now attracting increasing attention because of the development of basin analysis techniques. Some aspects have been discussed by Horowitz (1976), Sclater and Christie (1980), and Le Douaran and Parsons (1982).

Sediment density and porosity result from the history of interaction of grain and interstitial fluid compositions, overburden pressure, temperature, and regional permeability since deposition, which involves diagenesis and recrystallization as well as mechanical compaction. The mixture for any particular section will be unique, and approximate solutions are thus required. The approach favored at present assumes that, for a constant initial lithology, all other time-dependent and temperature-dependent effects essentially simulate compaction under a mechanical load. An empirical curve of porosity or density versus depth is constructed for each of a series of lithologies; differences between curves reflect the different mechanical strength and chemical properties of each lithology. The section of interest is then progressively "unloaded" up one or more appropriate porosity or density curves, and instances of tectonic disturbance, substantial erosion, or overpressuring in either the section of interest or the comparison curve, which could invalidate the procedure, are noted.

This seems a reasonable approach for the section at Site 516, which is without major hiatus and, apart from the partly volcanogenic Unit 4 , is a dominantly calcareous ooze-chalk-limestone succession, as the shipboard carbonate bomb measurements illustrate (Fig. 6A and site chapter, Site 516, this volume). Figures $6 \mathrm{~B}$ and $6 \mathrm{C}$ show values of wet-bulk density and porosity, respectively, measured aboard ship on samples from Holes 516 and $516 \mathrm{~F}$. Those measured by gravimetric methods on $516 \mathrm{~F}$ samples from below $180 \mathrm{~m}$ depth have been validated by Carlson and others (this volume), but some doubt has been cast on the validity of physical properties measurements on HPC samples from Hole 516, because of disturbance during the coring process (Walton et al., this volume). Although this concern is justified, the degree of disturbance probably has a more severe effect on some properties than on others; magnetic reversal stratigraphy, for example, is largely unaffected (see site chapter, Site 516, this volume; Suzyumov and Hamilton, this volume; Berggren et al., this volume). The values of wet-bulk density and porosity displayed here 


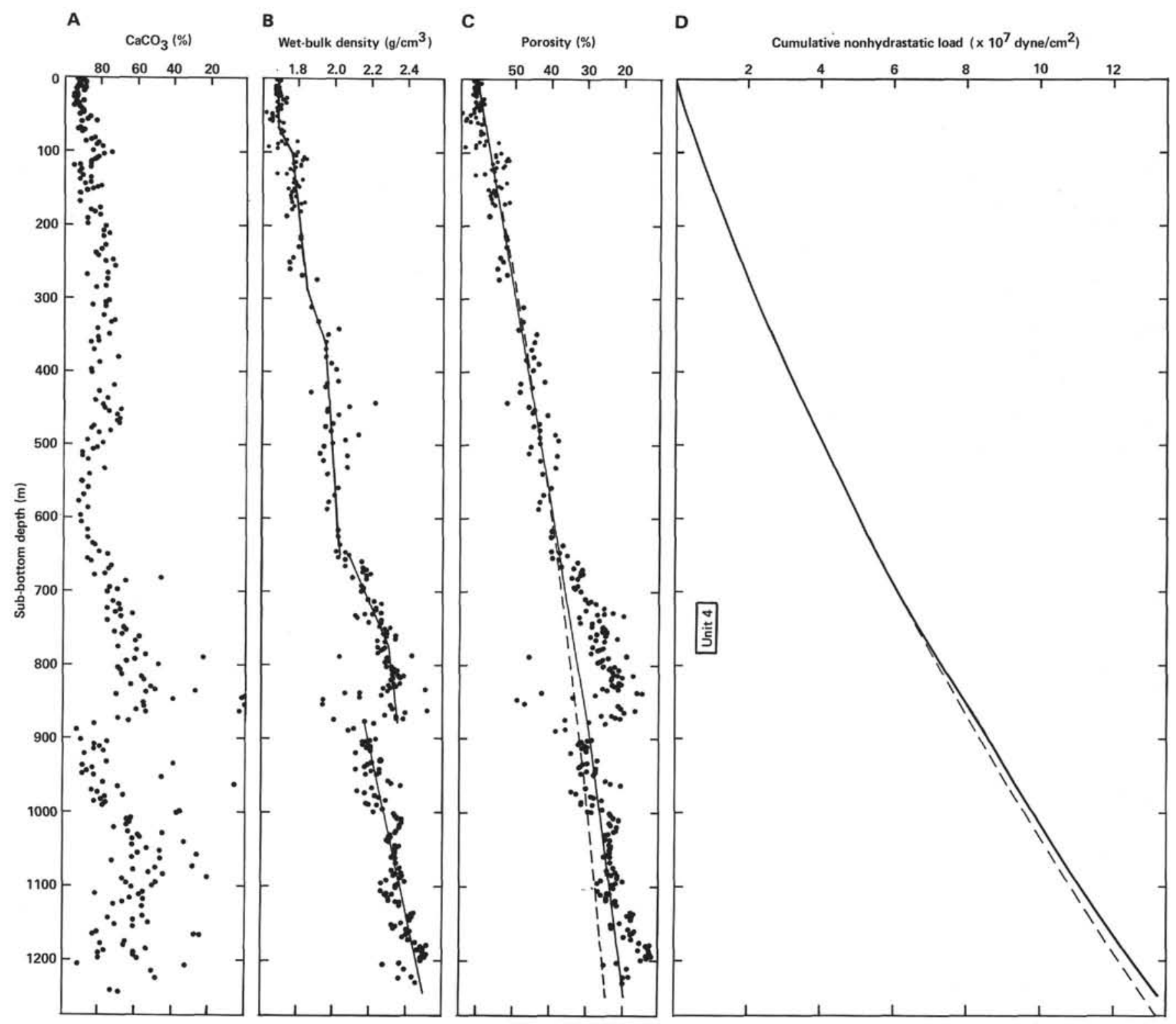

Figure 6. Site 516 shipboard measurements of A, carbonate percentage; B, wet-bulk density (with model); C, porosity, with porosity-depth (dashed) and porosity-load (solid) curves fitted; D, load-depth curves, from density model in Figure 6B (solid) and from porosity-load curve in Figure 6C (dashed).

above $180 \mathrm{~m}$ are likely to be better than those obtained from shallow depth in earlier, rotary-drilled DSDP holes, in which core disturbance was greater. For this reason, and because the Site 516 section is particularly densely sampled, it is used here as its own reference section in preference to compiling a reference section from the literature, which for this limited and shallow depth range is rather sparse.

Densities increase and porosities decrease steadily downsection, except for the middle Eocene Unit 4, which contains partly volcaniclastic slumps and turbidites and thin altered ash beds (see Bryan and Duncan, this volume). Within Unit 4, the highest densities were measured on silicified pelagic limestones, and the dominantly volcanogenic layers gave comparatively low values. We have suggested that (1) the admixture of volcanic debris, particularly silica, increased diagenesis and recrystallization of the calcareous component and (2) the massive basal slump was "precompacted", to cause the higher densities (site chapter, Site 516, this volume; Barker et al., this volume).

The line drawn through density values in Figure 6B produces the solid line in Figure 6D, a curve of cumulative nonhydrostatic load, assuming an equilibrium response of the sediment (i.e., that pore pressure is hydrostatic, Sclater and Christie, 1980, appendix A). The sediments could be unloaded along this curve, stripping off the upper layers and raising the remainder, were it not for Unit 4, which not only shows an anomalous density-depth relationship requiring a different reference curve but also presents an additional load to the underlying carbonates. This is illustrated in Figure $6 \mathrm{C}$, by the 
two curves fitted by least squares to porosity data from the uppermost $635 \mathrm{~m}$ at Site 516, above Unit 4 . The dashed line in Figure $6 \mathrm{C}$ is the exponential curve of porosity $(f)$ against depth $(z), f_{z}=f_{0} \mathrm{e}^{-c z}$ (the exponential form is generally considered appropriate, see Sclater and Christie, 1980, appendix A). The computed coefficients are $f_{\mathrm{o}}=61.4 \%$ and $\mathrm{c}=0.73 / \mathrm{km}$, where $z$ is in $\mathrm{km}$. These values compare well with coefficient values quoted by Sclater and Christie (1980) except that their $f_{\mathrm{o}}$ is higher; because their values are derived largely from older, rotary-cored DSDP data, the value computed here is probably more representative of in situ values.

The dashed curve in Figure 6C, if extrapolated below $635 \mathrm{~m}$, would not be expected to fit Unit 4, as previously explained, but neither is it a good fit to the underlying carbonates. This is because Unit 4 also presents an additional load. A better fit is provided by the solid line in Figure $6 \mathrm{C}$. This is also a least squares fit to porosity data from the uppermost $635 \mathrm{~m}$, but of an exponential curve of porosity $(f)$ against nonhydrostatic load $(\alpha)$ obtained from Figure 6B and 6D: $f_{0}=60.5 \%$ and $\mathrm{d}=$ $0.848 \times 10^{-8} \mathrm{~cm}^{2} /$ dyne, where $f_{\alpha}=f_{\mathrm{o}} \mathrm{e}^{-\mathrm{d} \alpha}$. This comparison points out a potential danger of unloading along porosity-depth curves in mixed-lithology sections and suggests that porosity-load curves might be more useful. Because porosity and load are related, a porosity-load curve will reduce to a porosity-depth curve for a constant lithology. Similarly, the porosity-depth curve may be integrated to produce a load-depth curve. The load-depth relationship derived from the solid curve fitted in Figure 6B has been used to generate the dashed line in Figure 6D, which is more appropriate than the observed load-depth curve (solid line) for unloading the calcareous sediments beneath Unit 4. Above Unit 4, it coincides with the observed curve.

To unload Unit 4 itself presents a problem, because a porosity-depth curve computed from Unit 4 values alone produces an unrealistic initial porosity $(>100 \%)$, probably because Unit 4 contains a compositional gradient. The arbitrary solution adopted is to assume that the departure from the pure carbonate porosity-load curve at any point within Unit 4 is one-third original ("precompaction," with $f_{\mathrm{o}}<60 \%$ ) and two-thirds acquired (enhanced diagenesis, leading to a steeper compaction curve) and unload accordingly.

Figure 7 shows the complete sediment compaction history at Site 516, unloaded as described and balanced above and below an isostatic datum. That is, the isostatic depression produced by the sediment load has been computed for each chosen time interval, using seawater

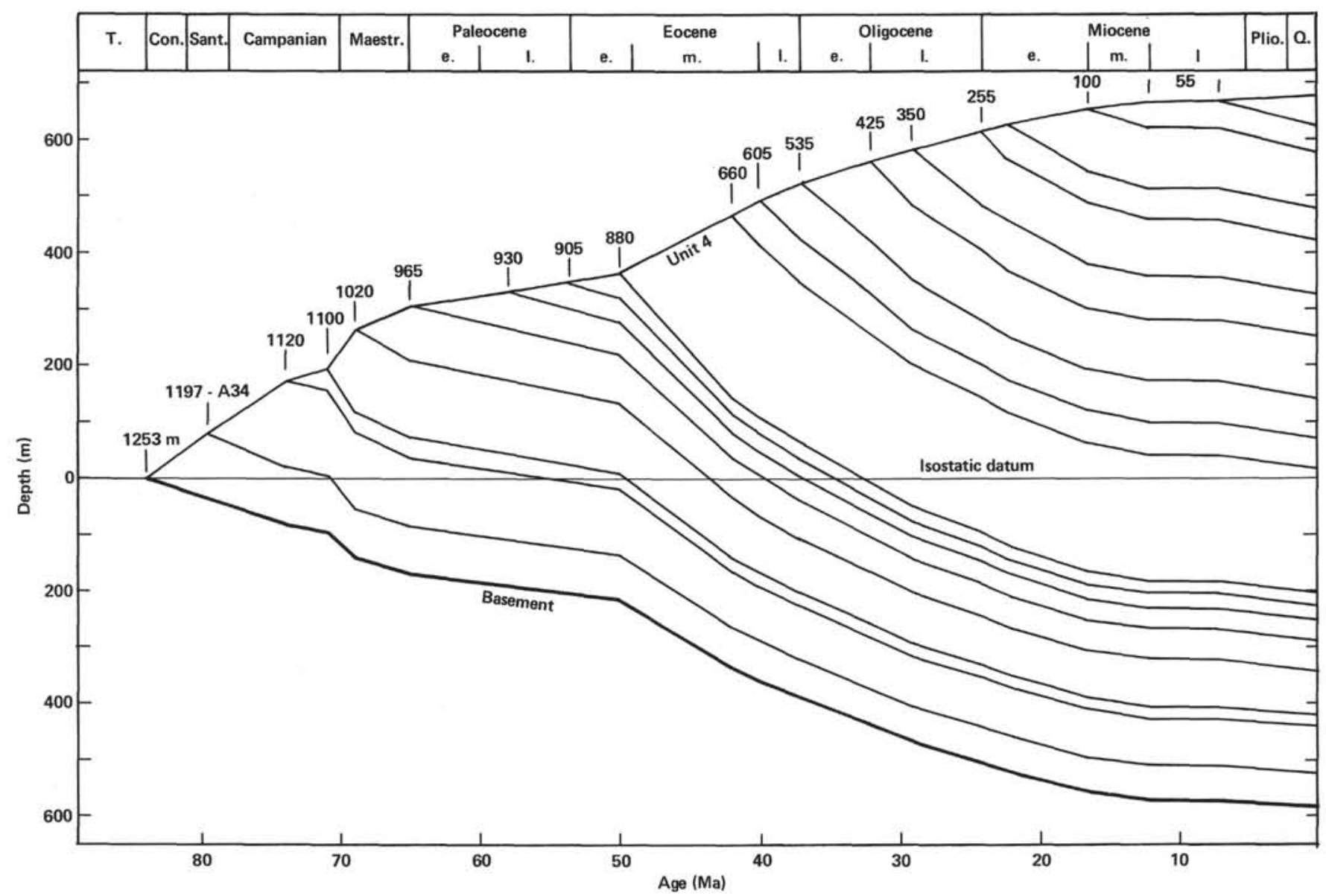

Figure 7. Site 516 sediment thickness versus time, corrected for compaction using Figure 6, and plotted with respect to isostatic datum as illustrated in Figure 5D. Magnetostratigraphic and biostratigraphic control comes from site chapter, Site 516 (this volume). See text for further explanation. $\mathrm{T}$. = Turonian. 
and asthenospheric densities of $1.025 \mathrm{~g} / \mathrm{cm}^{3}$ and $3.3 \mathrm{~g} /$ $\mathrm{cm}^{3}$, respectively (Figure 5D), and the base of the sediment column depressed by this amount in Figure 7 beneath the no-sediment level of igneous basement.

To illustrate the unloading process, consider the 15 -m-thick slide at the base of Unit 4 at Site 516. It is largely composed of Maestrichtian limestones identical to those now found $130-150 \mathrm{~m}$ deeper in the section and displays sedimentary structures suggesting emplacement as an ooze or chalk. If the sedimentary section at its site of origin was identical to that at Site 516 in the late early Eocene, before it moved, how far below the seabed was it? In the units of Figure 6D, the present nonhydrostatic load on the uppermost lower Eocene sediments $(880 \mathrm{~m})$ is $8.25 \times 10^{7}$ dyne $/ \mathrm{cm}^{2}$ and on the Maestrichtian sediments $(1020 \mathrm{~m}) 9.90 \times 10^{7}$ dyne $/ \mathrm{cm}^{2}$. If the post-early Eocene load is removed, the remaining load on the Maestrichtian sediments is $1.65 \times 10^{7} \mathrm{dyne} / \mathrm{cm}^{2}$, equivalent in Figure 6D to a depth below the seabed of $230 \mathrm{~m}$, where the porosity is about $52 \%, 9 \%$ less than the seabed value. This result provides a maximum value for precompaction within Unit 4 and an indication of the minimum depth extent of middle Eocene slumping.

\section{Basement Compaction}

Compaction of basement by subsequent sediment load, as opposed to compaction of the sedimentary cover, is usually neglected. However, the dipping reflector sequence beneath basaltic "basement" at Site 516 is interpreted as interbedded subaerial lavas and shallow marine or alluvial sediment (Barker et al., this volume), by comparison with similar sequences elsewhere (Hinz, 1981; Hinz and Krause, 1982; Mutter et al., 1982; Roberts et al., 1982). Direct evidence for the relative proportion of lava and sediment, which will control the amount of compaction, is sparse. Roberts and others (1982) report that the sequence drilled during DSDP Leg 81 on Hatton Bank was dominantly basaltic, with only thin interbeds. In many locations also, interval velocities from velocity analysis of multichannel reflection profiles (Mutter et al., 1982) and sonobuoy refraction velocities (Hinz and Krause, 1982) are high, approaching $5 \mathrm{~km} / \mathrm{s}$, which indicates the predominance of lavas. Nevertheless, Iceland, the present-day model for this sequence, has alluvial sediments in some areas susceptible to further plateau basalt cover, and, on the Rio Grande Rise, the sequence has been correlated with a layer having sonobuoy refraction velocities of only $3.6 \mathrm{~km} / \mathrm{s}$. Interval velocities obtained from UTMSI reflection profiles close to Site 516 average $3.9 \mathrm{~km} / \mathrm{s}$, although they may not be completely reliable (Barker et al., this volume).

Using Sclater and Christie's (1980) porosity-depth parameters for sands and assuming incompressible lavas and an original sediment component of (1) $20 \%$ and (2) $50 \%$, we can calculate the amount of compaction of an original $1 \mathrm{~km}$ of section. It is quite small; under its own load, the column would have been compacted to (1) $969 \mathrm{~m}$, (2) $932 \mathrm{~m}$ by the time that eruption ceased. The additional load of the entire $1252 \mathrm{~m}$ sediment column at Site 516 produces an extra compaction of only (1) $37 \mathrm{~m}$ and (2) $73 \mathrm{~m}$. Any such effect is probably less than $50 \mathrm{~m}$, because a $20 \%$ sediment component seems generous.

\section{Regional or Local Isostatic Compensation?}

In the preceding discussion, we have assumed that isostatic compensation for the load of the sedimentary section at the site is effectively local. However, the lithosphere has a finite strength, and a concentrated load is compensated partly beneath that load and partly over the surrounding area. Thus, sedimentation at Site 516 has to be compared with that in surrounding areas, and the effect of any differences must be assessed.

The lithosphere may be modeled as a thin elastic plate floating on a liquid (Brotchie, 1971); its effective elastic thickness $(T)$, which determines the areal extent of compensation, has been shown by Watts and others (1980) to be about one-third of the thermal or seismic thickness $Z_{t}$. Brotchie (1971) defines a "radius of effective stiffness" ( $l$ ), a function of $T$; for differently distributed loads (disc, annulus, point), the standard measures of the range of compensation (such as half-maximum, onequarter to three-quarters maximum) vary between $l$ and 1.5l. Figure 8 is a schematic sectional diagram of the Rio Grande Rise, modeled as a circular feature with an axis of symmetry at the central graben. Although the Rise is oval rather than round, and the graben is linear, this model is reasonable for the regional variation of sedimentation and erosion. The radii of the five different annular provinces are those appropriate to a northsouth section through Site 516 , which lies midway through the shoulder annulus. The characteristics of deposition in each annulus, compared to deposition at Site 516 and assessed on the basis of reflection profiles (Barker et al., this volume), are summarized in Table 2.

Before the middle Eocene, the present graben, guyot, and shoulder provinces were probably a single plateau province, receiving sediment at the same rate as Site 516 except directly after formation, when some more elevated areas may still have been subaerial. The lithosphere was then very thin and $l$ was small, so that compensation was quite local and such variations did not affect Site 516. Detrick and Watts (1979) have demonstrated such local compensation for the congruent eastern Walvis Ridge. Sediments in the basin province were thicker and on the slopes slightly thinner than on the plateau, but the small values of $l$ would limit the effects of such differences at Site 516 .

During the middle Eocene event, sedimentation was very uneven. Subaerial erosion and slumping reduced the load on the guyot (and graben) province, causing isostatic uplift, although an unknown amount of volcanism in the early middle Eocene would have compensated in part. In the shoulder province, Unit 4 was thicker towards the guyot, source of slide debris and turbidites, and thinner toward the slope. Sedimentation at Site 516 may be slightly less than the shoulder average (Figures 9 and 10 of Barker et al., this volume). It is hard to tell, but middle Eocene sedimentation on the slope and in the basin may have been less than at Site 516. Crough's (1978) model suggests that the lithosphere beneath the Rise had thinned to its 25 Ma thick- 


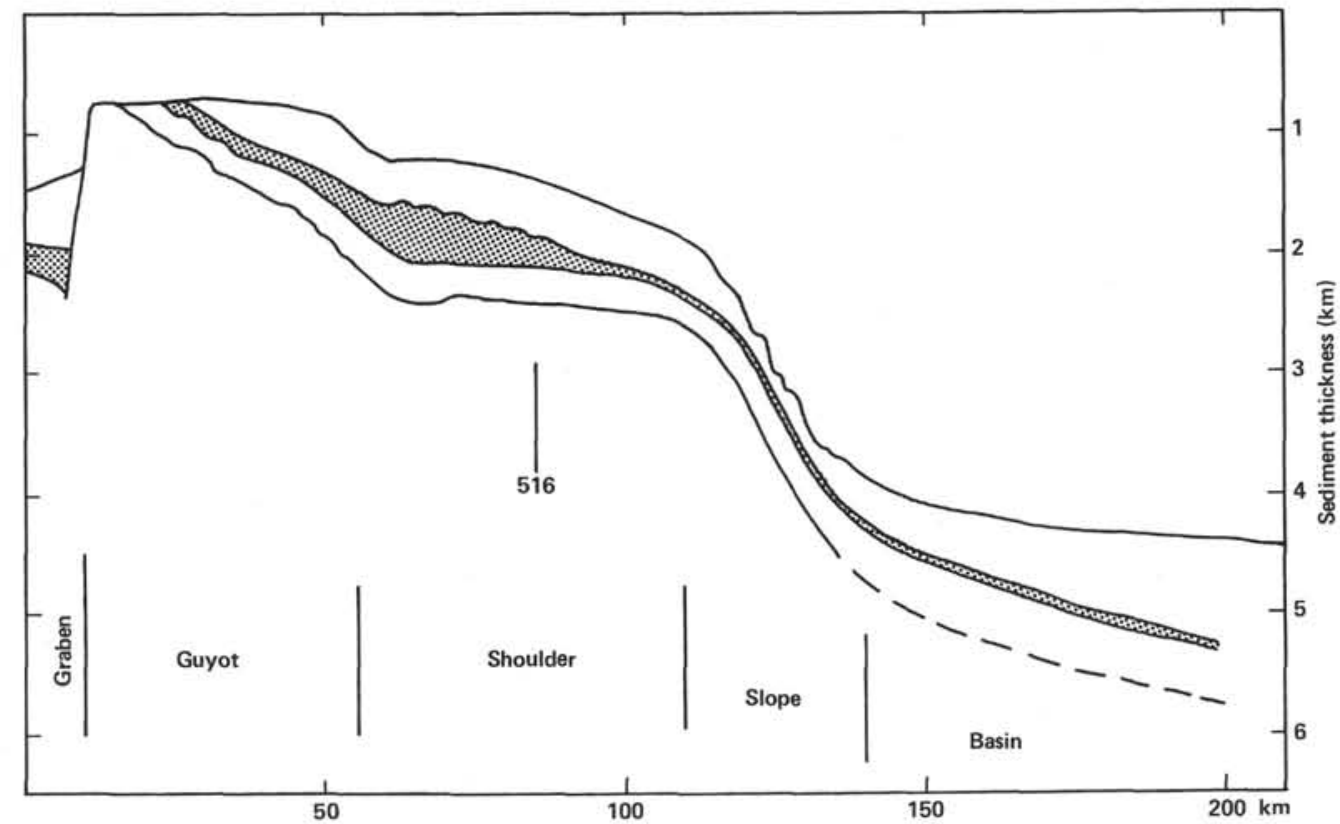

Figure 8. Schematic south-north section through annular sediment provinces of Rio Grande Rise, with radii proportional to section through Site 516, and sediment thickness from reflection profiles (Barker et al., this volume; Gamboa et al., this volume). Middle Eocene sequence is stippled. Site 516 lies midway through shoulder province.

Table 2. Sedimentation in Rio Grande Rise annuli compared with Site 516 (see Fig. 8).

\begin{tabular}{|c|c|c|c|c|c|c|}
\hline Age & Graben & Guyot & Shoulder & Slope & Basin & Range $1.5 t^{\mathrm{a}}(\mathrm{km})$ \\
\hline Post-middle Eocene & Similar & Thin & Thin & $\begin{array}{l}\text { Thin, } \\
\text { erosion }\end{array}$ & Thicker & $50-65$ \\
\hline middle Eocene & Erosion & $\begin{array}{l}\text { Erosion, } \\
\text { slumping. } \\
\text { thin }\end{array}$ & $\begin{array}{l}\text { Sloping, } \\
\text { slightly } \\
\text { thin }\end{array}$ & Thin & Thin? & $\begin{array}{l}50 \text { and much } \\
\text { less }\end{array}$ \\
\hline $\begin{array}{l}\text { Late Cretaceous- } \\
\text { Paleocene }\end{array}$ & Similar & Similar & Similar & Thin? & Thicker & $20-50$ \\
\hline
\end{tabular}

a / is the "radius of effective stiffness," as defined in Brotchie (1971).

ness $(T \sim 15 \mathrm{~km}, l \sim 35 \mathrm{~km})$ in the middle Eocene, but the tilt of the guyot province, volcanism, and downfaulting of the graben suggest a much thinner lithosphere there and demonstrate decoupling from Site 516. Probably only the sediment wedge on the shoulder province itself would have affected Site 516 and would make an estimate of subsidence based on local isostatic response slightly low.

Post-middle Eocene sedimentation was also uneven, and the cooling and thickening of the lithosphere makes it more likely that this affected Site 516. Sediment thicknesses in the graben are similar to, and in the basin may be no greater than, at Site 516, at least close to the Rise. However, post-middle Eocene sedimentation on the guyot has been confined to a prograded wedge on the outer margin and a very thin layer on top. The guyot would have remained subaerial for some time after thermal doming ceased, uplift partly compensating for subaerial erosion. Even after erosion to wave-base and resubmergence, the top was swept by strong bottom currents. Sediment winnowed from the top is thought to have provided the initial load for density currents which, directed by the uneven Unit 4 slide topography, reduced sedimentation in other parts of the shoulder province, away from Site 516, and helped cut the canyons in the slope province (Johnson and Peters, 1979). Thus Site 516 (chosen for a more complete Neogene section) has thicker sediments than the provinces on either side and other parts of the shoulder province, and $l$ is sufficiently large for this to be significant. I estimate that as much as one-quarter of the $230 \mathrm{~m}$ of basement subsidence attributed to the post-middle Eocene sediment load in Figure 7 may be excessive. This post-middle Eocene excess of about $60 \mathrm{~m}$ is virtually the only error resulting from the assumption of local rather than regional isostatic compensation for the sediment load around Site 516 and lies well within the limits of other uncertainties involved in computing the subsidence curve.

\section{Eustatic Sea Level Change}

Figure 9, which illustrates the subsidence history computed for Site 516, incorporates two contrasting estimates of global eustatic changes in sea level since the mid-Cretaceous (Pitman, 1978; Vail et al., 1977). Pitman's smooth curve is based on changes in volume of the mid-ocean ridges resulting from spreading rate changes. The curve is restored to its full amplitude, having here a mid-oceanic datum rather than that of continental freeboard, and has been used to correct all of the subsidence curves shown in Figure 9. Vail and others' (1977) curve is based on interpreted multichannel seismic profiles, with well control, from many continental margins around the world. It includes a series of regressive-transgressive events of short duration but large amplitude and global extent, interpreted as eustatic sea level changes. Despite concern about a mechanism for events of such magnitude (before the present Neogene glaciation) and despite alternative explanations for parts of the curve by Pitman (1978) and Watts (1982), more recent versions (Vail 


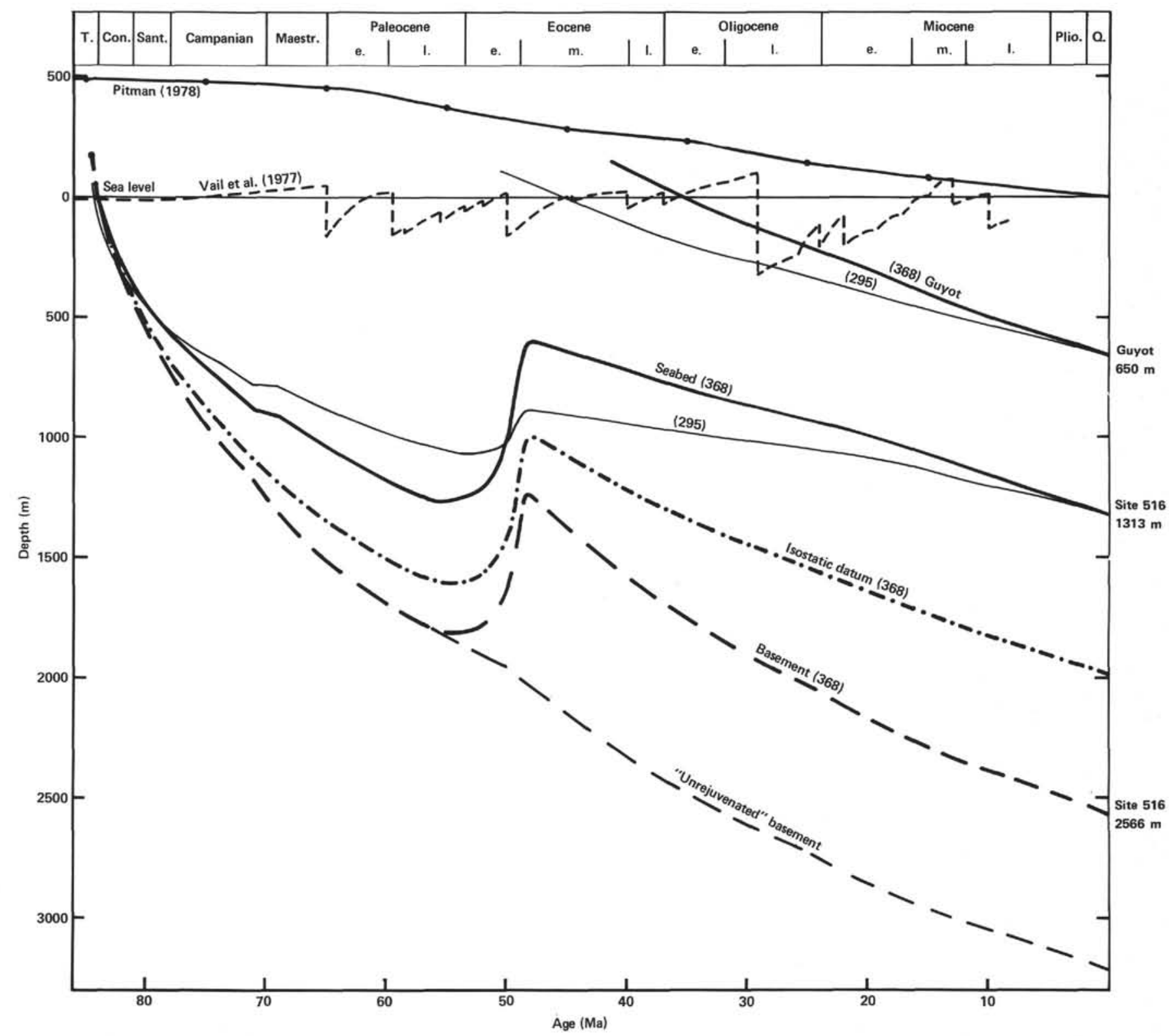

Figure 9. Subsidence history of area around Site 516, Rio Grande Rise. Numbers enclosed in parentheses represent coefficients used in deriving subsidence curves; for explanation, see text. T. $=$ Turonian.

and Hardenbol, 1979; Vail and Todd, 1981; Hardenbol et al., in press) are substantially similar. Vail and others' (1977) curve is based on the compensated Pitman (1978) curve for depth calibration; in view of the controversy surrounding interpretation of their curve, I have not attempted a similar amplification. It is shown unmodified in Figure 9 and considered only qualitatively.

\section{Subsidence Curves}

The subsidence curves that form Figure 9 were computed by use of the data and principles already described. The principal, preferred subsidence history for the area around Site 516 is contained in the three subparallel thick lines, representing isostatic datum (dotdashed line) with isostatically depressed basement beneath it (dashed line) and the seabed (solid line) above, distributed about the isostatic datum in accord with Figure 7. The lines cross sea level at $84.0 \mathrm{Ma}(0.5 \mathrm{Ma}$ after subaerial eruption at the ridge crest) and end at their respective present-day water depths. All have been corrected for the eustatic fall in sea level by use of Pitman's (1978) smooth curve displayed at the top of Figure 9. The correction effectively shifts this curve down to become the horizontal sea level line.

The three curves all have older and younger smooth sections separated by a sharp step representing the effects of the middle Eocene off-axis event. The thermal subsidence model is best considered with respect to the isostatic datum curve (dot-dash), which is free of sediment loading effects (but does incorporate the eustatic correction). It falls from sea level at a rate given by $h_{t}=$ $368\left(t^{1 / 2}-0.5^{1 / 2}\right)$, until the Paleocene, when "rejuvena- 
tion" starts. The younger part of the same curve, after rejuvenation, is computed back from the present-day depth, using the same $368 t^{1 / 2}$, where $t$ is now $73 \mathrm{Ma}$, having started with a $25 \mathrm{Ma}$ age $48 \mathrm{Ma}$ ago (K-Ar biotite age 47.4 Ma, Bryan and Duncan, this volume). The second, shorter thick solid line represents the subsidence of the guyot top, now at $650 \mathrm{~m}$ below sea level, computed by the same means. This assumes that the guyot and shoulder (516) provinces of the Rise would have subsided together, once the underlying lithosphere had cooled and thickened a little and subaerial erosion had ceased, despite their earlier manifest decoupling. The intersection of this curve with sea level provides a useful model constraint, considered below.

The younger and older sections of the isostatic datum curve are joined by a section whose form is that of the rise of the Hawaiian hot spot swell ahead of the islands. The Hawaiian rise is very steep (Crough, 1978, figure $11)$, becoming as steep in its upper part as the subsidence curve of very young ocean floor (which in itself may be an important clue to the rejuvenation mechanism). The rise in Figure 9 has been made less steep, because not all of the uplift required to join the sections may be attributed to thermal rejuvenation. The total amount required is $650 \mathrm{~m}$, as shown by the excessively deep intersection made on the $\mathrm{O} \mathrm{Ma}$ axis by the unrejuvenated basement curve (thinner dashed line). The Rise near Site 516 "loses" only $11.5 \mathrm{Ma}$, equivalent to $240 \mathrm{~m}$, by rejuvenation to a $25 \mathrm{Ma}$ age at $48 \mathrm{Ma}$. The remaining $410 \mathrm{~m}$ are attributed to irreversible uplift of compositional origin, for reasons already described.

Constraints and Alternatives. Although the subsidence curve already described is compatible with all of the available data, and its mixture of thermal (reversible) and compositional (irreversible) middle Eocene uplift seems plausible, it is a useful exploration of the available constraints to examine the alternatives to the $410 \mathrm{~m}$ irreversible component. Some of the possibilities ("basement compaction", regional isostatic compensation) have already been shown incapable of accounting for an offset of this magnitude.

One option is to delay the time of the marine transgression to $81.2 \mathrm{Ma}$ ago, 3.3 $\mathrm{Ma}$ after formation at the ridge crest. This assumption makes the initial subaerial height $460 \mathrm{~m}$ and the width of the Rio Grande Island $240 \mathrm{~km}$, which is rather large. The absence of any seismic reflection evidence of substantial topographic relief on the basement reflector, which high initial relief and prolonged subaerial erosion should produce, and the absence of a thick terrigenous basal sediment layer that typifies the shelves of a large landmass, suggest early submergence of the Rise. Other consequences of delayed submergence would be subsidence directly after submergence less than half as fast as in the preferred model and a seabed depth curve consistently $410 \mathrm{~m}$ higher before the Eocene, which raise other problems (next section).

A second option is to assume a less steep subsidence curve. The thin solid line in Figure 9 that joins sea level at $84 \mathrm{Ma}$ to $1313 \mathrm{~m}$ present depth is produced using $295 t^{1 / 2}$, Heestand and Crough's (1981) distal or "uncon- taminated" slope coefficient. By adjusting the submergence time to 0.1 rather than $0.5 \mathrm{Ma}$ after formation, this curve can be made to produce a fit that includes thermal rejuvenation but needs no irreversible component. The use of this coefficient in a quintessentially hot spot environment seems most inappropriate, and the value of its inclusion in Figure 9 may be that it shows how far such an extreme variation will displace the subsidence curve. There is, however, the more concrete problem of its effects on the guyot. The shorter thin line in Figure 9 is the same distal (295) curve. It intersects sea level about $45 \mathrm{Ma}$ (middle Eocene), compared with $35 \mathrm{Ma}$ (early Oligocene) for the preferred proximal (368) curve. The highest turbidite at Site 516 containing reefal debris, indicating very shallow water upslope, is in Core 516F-50 (NP17, late middle Eocene, $41 \mathrm{Ma}$, Tjalsma, this volume), when the nominal sub-bottom depth of the distal (295) curve is $80 \mathrm{~m}$. The absence of such turbidites higher in the section at Site 516, however, might not indicate subsidence of the adjacent guyot below wave-base at that time, but could merely reflect the channeling of turbidity currents away from the site by the uneven slide topography upslope (Barker et al., this volume). This interpretation is supported by Johnson and Peter's (1979) report of a very shallow-water lower Oligocene benthic fauna in a displaced unit sampled by piston coring near Site 357, farther downslope from the same guyot. This occurrence is compatible with the proximal (368) curve, but cannot be reconciled with the distal (295) curve even if the large excursions of Vail and others' (1977) sea level curve are invoked. Both subsidence curves intersect the late Oligocene Vail excursion, at depths of 120 and $270 \mathrm{~m}$ from the Pitman curve (220 and $370 \mathrm{~m}$ from Vail's previous maximum), indicating that the Rio Grande Rise may have some value as a region for investigating the amplitude of this excursion.

\section{Paleoecologic Depth Estimates}

The subsidence history derived here is based almost completely on tectonic considerations, so that paleontologic and associated sedimentologic depth indicators provide an independent test of the conclusions. The one exception is the use of Milliman's data (this volume) to establish the subaerial or very shallow marine origin of basal lavas at Site 516. The seabed at the site, according to the preferred model (Fig. 9), reached a maximum depth of $1250 \mathrm{~m}$ in the late Paleocene and a minimum of $600 \mathrm{~m}$ in the early middle Eocene. Thus, it has not previously been as deep as at present $(1313 \mathrm{~m})$ and has remained within the middle bathyal benthic depth zone since the late Santonian (79 Ma).

Thiede's (1977) study of the subsidence history of the Rise combined data from different areas. The potential dangers of this procedure are now more evident. The crestal region of the Rise, for example, experienced a quite intense middle Eocene volcano-tectonic disturbance, involving differential uplift by tilting and faulting. Pre-middle Eocene paleodepth data from the crestal region cannot therefore be combined with data from Site 516. One lower Oligocene datum (previous section) has already been used, but precise biostratigraphic and 
environmental data about one other (dredge Sample DRO2 used by Thiede, 1977) is lacking. Also, the use of data from Site 21 (Fig. 2) does not seem justified, because it is on a separate component body of the Rise that could have experienced a completely different subsidence history. Use of Site 357 data, however, is reasonable; it is only $40 \mathrm{~km}$ from Site 516 on the same northern shoulder of the Rise.

Sites 357 and 516 probably had the same thermal subsidence history, because the basement age at Site 357 is only 0.5 Ma greater (by Rabinowitz and LaBrecque's 1979 data). The only difference between them is sedimentation and initial depth. The isostatically compensated sediment load at Site 357 has been removed by use of the Site 516 load curve (Fig. 6), which is compatible with the measured densities (Supko, Perch-Nielsen, et al., 1977, p. 246). Removal of the sediments decreases the depth difference between the sites from $773 \mathrm{~m}$ now to about $550 \mathrm{~m}$ in latest Santonian (Fig. 10). This calculation is valid provided that the amount of sediment between the base of the hole at Site 357 (796 m subbottom) and incompressible basement is small; using regional sedimentation rates, we assume that basement lies at $850 \mathrm{~m}$ sub-bottom. By these assumptions, the computed paleodepth of (ridge crest) basement at Site 357 is $350 \mathrm{~m}$ below sea level. For the depth instead to be zero (i.e., subaerial basement, like Site 516) at least $600 \mathrm{~m}$ (present thickness) of additional sediment would have to intervene between basement beneath Site 357 and the base of the hole. This option would imply extremely high sedimentation rates, which at present appear unlikely.

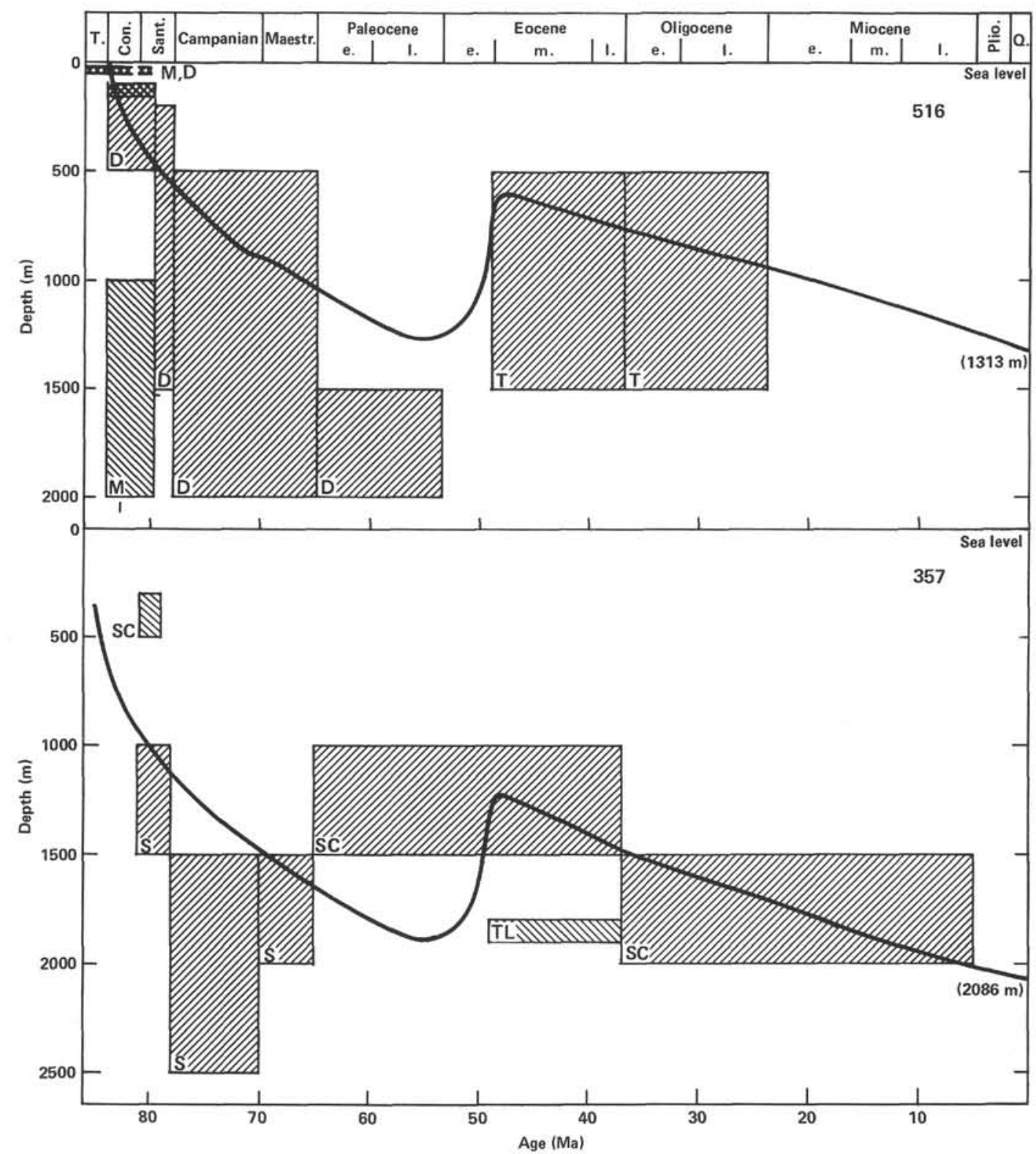

Figure 10. Comparison of tectonic subsidence curves for Sites 516 and 357 (for derivation, see text and Fig. 9) with paleoecologic depth estimates listed and identified in Table 3. T. = Turonian. 
Table 3 shows Milliman's paleodepth estimates (this volume) for Site 516 sediments, and others by Dailey (this volume) and Tjalsma (this volume) based on benthic foraminifers. At Sites 21 and 357, in sediments of similar lithologies and likely paleodepths, Benson (1977) used ostracodes as paleodepth indicators (Table 3), but they were inexplicably absent in pre-Oligocene sediments at Site 516 (Benson and Peypouquet, this volume). All of these estimates are compared with the subsidence curves for Sites 516 and 357 in Figure 10.

The correspondence between tectonic and paleoecologic depth estimates is not close. The paleoecologic data come mostly from this volume and the corresponding Leg 39 publication (Supko, Perch-Nielsen, et al., 1977) and are therefore to some extent preliminary; they lack resolution in both depth and age. The only internal conflicts are between Milliman's and Dailey's estimates for Core 516F-123, that involving Tjalsma and Lohmann's (in press) revision of the Site 357 site chapter estimate for part of the Eocene, and between estimates based on benthic foraminifers and Inoceramus for the early Santonian at Site 357. In comparison with the tectonic curves, however, the paleoecologic estimates are generally deeper. It is difficult to eliminate this discrepancy by modifying the tectonic curves. The zero depth for Site 516 is fixed, and the slope of the older part of the subsidence curve is already slightly steeper than the average oceanic curve, with no precedent for use of an even steeper curve. The post-middle Eocene depths can only be increased at the expense of decreasing the earlier depths, by using the smaller, distal coefficient (thin line in Fig. 9), and this change remains unattractive. The Site 357 curve in Figure 10 can be made deeper only by assuming that rejuvenation there was more effective (farther from the crest!) than at Site 516.

An explanation may be found within the paleoecologic sphere. Depth estimates depend partly on comparison with modern forms of similar morphology and partly on comparison with assemblages of similar age in

Table 3. Paleoecologic depth estimates, Holes 516F and 357.

\begin{tabular}{|c|c|c|c|c|}
\hline Depth $(\mathrm{m})$ & Source & Age & Comments & $\begin{array}{c}\text { Core } \\
\text { (or core-section) }\end{array}$ \\
\hline \multicolumn{5}{|l|}{ Hole 516F } \\
\hline $500-1500$ & $\mathrm{~T}$ & Oligocene & & \\
\hline $500-1500$ & $\mathrm{~T}$ & middle late Eocene & & \\
\hline $1000-1500$ & $\mathrm{~T}$ & late Maestrichtian & Slide at base Unit 4 & $79-2$ \\
\hline $1500-2000$ & D & Paleocene & Shallow lower bathyal & $89-5$ to $83-2$ \\
\hline $500-2000$ & D & Campanian + Maestrichtian & $\begin{array}{l}\text { Middle to shallow lower } \\
\text { bathyal }\end{array}$ & 113 to 89.5 \\
\hline $200-1500$ & D & late Santonian & Upper to middle bathyal & 119 to 116 \\
\hline $100-500$ & D & & $\begin{array}{l}\text { Deeper neritic or shallow } \\
\text { bathyal }\end{array}$ & 123 to 121 \\
\hline $1000-2000$ & M & & Deep water, shallow influx & 123 \\
\hline & M & Santonian-Coniacian & $\begin{array}{l}\text { Upper slope or deeper + } \\
\text { mixing } \\
\text { Open marine shelf sea }\end{array}$ & 124 \\
\hline $100-150$ & M,D & & Outer shelf-upper slope & 124 \\
\hline $20-50$ & $\mathrm{M}, \mathrm{D}$ & & Open shelf, high energy & 125 \\
\hline 20 & $\mathrm{M}$ & & Shallow subtidal, quiet & 126 \\
\hline \multicolumn{5}{|l|}{ Hole 357} \\
\hline 1000 & $\mathrm{Be}$ & Cenozoic & Ostracodes & \\
\hline $1500-2000$ & sc & Oligocene, Miocene & & \\
\hline $1800-1900$ & $\mathrm{TL}$ & late early-late Eocene & & \\
\hline $1000-1500$ & SC & Paleocene-Eocene & & \\
\hline 1000 & SC & Cretaceous & Benthic foraminifers & \\
\hline $1500-2000$ & s & Maestrichtian & & 33,32 \\
\hline $1500-2500$ & s & Campanian & & 40 to 36 \\
\hline $1000-1500$ & s & Santonian & & 48 to 42 \\
\hline $300-500$ & sc & early Santonian & Inoceramus & 51 to 43 \\
\hline
\end{tabular}

other areas where depth estimates have already been made. Depth bias may affect both these procedures. I would not want to attempt a discussion of the complexities of comparing ancient and modern forms in oceans in which depth and regional distributions of temperature, salinity, and nutrients have changed considerably since the mid-Cretaceous and downslope contamination is a frequent complication. The comparison of localities, however, offers more familiar groind. Although the universality of thermal and isostatic subsidence and sediment compaction in the oceans, in sedimentary basins, and on passive margins is now generally accepted, accurate corrective uplift may not yet have been applied to all of the sections being used for comparison. The Rio Grande Rise is not ideal as a future reference site, because of its middle Eocene tectonic event whose vertical extent is somewhat speculative. However, understanding of off-axis hot-spot tectonism is increasing, and more precise paleodepth estimates than made here may be possible soon. Aseismic ridges clearly have some potential as paleodepth reference sites; they span a wide depth range in mid-ocean, are small enough to limit the extent of local upwelling, and lack the dilution, instability, inaccessibility, and uncertain compaction history of the thick, largely terrigenous sediment piles of the continental margins.

\section{CONCLUSIONS}

In this synthesis, I have evaluated DSDP Leg 72's contribution to an understanding of the tectonic evolution of the Rio Grande Rise and speculated about the relationship of the morphology of the Rio Grande RiseWalvis Ridge system to the inhomogeneities in the sublithospheric mantle that produced it. I also have attempted to construct a detailed subsidence history for the main body of the Rio Grande Rise, taking into account as many contributory factors as possible. The principal conclusions are as follows.

1) Basalt sampled at the bottom of Hole $516 \mathrm{~F}$, on the northern shoulder of the Rio Grande Rise, in $1313 \mathrm{~m}$ water depth, is transitional (T-type) mid-ocean ridge basalt, similar to that found on the eastern Walvis Ridge, which is of approximately the same age. Its ${ }^{40} \mathrm{Ar} /{ }^{39} \mathrm{Ar}$ radiometric age of $86.0 \pm 4 \mathrm{Ma}$ and less precise magnetostratigraphic and biostratigraphic information from the overlying sediments are essentially coincident with the estimate of $84.5 \pm 0.5 \mathrm{Ma}$ for the age of the midocean ridge crest at the Site, based on regional magnetic anomaly data.

2) Sediments directly overlying basement indicate rapid subsidence from a very shallow initial depth. Reflection profiles around Site 516 show a dipping reflector sequence beneath the reflector associated with the basalt at the base of the hole. This sequence matches those that are now being found along many continental margins and being interpreted as a "subaerial seafloor spreading" facies association of subaerial lavas and shallowmarine or alluvial sediments. The sequence is found in other shallow areas of the Rio Grande Rise.

3) In combination, the above information indicates that the Rise was formed at a subaerial section of the mid-ocean ridge crest about $85 \mathrm{Ma}$ ago. 
4) Anomalously elevated areas of ocean floor often mark the destinations of jumps of the mid-ocean ridge crest; such an eastward jump had already been suggested for this region, on the basis of the asymmetric position of the younger magnetic anomalies and present spreading center with respect to the margins of this part of the South Atlantic. The ridge crest jumped (probably about $91 \mathrm{Ma}$ ago) to the western end of the Rio Grande Rise, at about $37^{\circ} \mathrm{W}$. The Rise itself subsequently formed on the South American flank of the new subaerial ridge crest, and the most easterly north-south component of the Walvis Ridge was formed on the congruent African flank.

5) This jump was preceded by another jump in the area to the north, at $106 \mathrm{Ma}$, which transferred part of the Angolan salt province to the Brazilian margin, and was succeeded by at least one other in the south at 71 Ma. All were eastward. Apparently, the present Tristan da Cunha hot spot first helped initiate South Atlantic opening and then, with the slow westward drift of the mid-ocean ridge, effected a series of captures of the ridge crest, causing it to jump eastward to return to the hot-spot center. The mechanism proposed for the jump involves reversal of the balance of ridge push forces on the young lithosphere by the cumulatively greater elevation of the hot-spot swell.

6) The massive Rio Grande and eastern Walvis bodies therefore represent off-axis volcanism that succeeded in capturing a ridge crest, and the younger, seamount province of the southwestern Walvis Ridge represents off-axis volcanism that failed. In view of the fact that fast-spreading lithosphere is nominally more susceptible to such a mechanism, it is interesting that the jumps were confined within the Cretaceous normal polarity interval and shortly afterwards, when spreading was faster than before or since.

7) The second main contribution of Site 516 drilling to an understanding of the tectonic evolution of the Rio Grande Rise comes from the middle Eocene Unit 4, which contains partly volcanogenic turbidites and volcanic ash beds and is floored by a massive slide of Maestrichtian limestone (then chalk). A K-Ar age of 47.4 $\pm 0.7 \mathrm{Ma}$, from fresh euhedral biotite with alkalic affinities from an ash bed, confines the volcanism to the early middle Eocene. The likely source of the slide and turbidite debris is the guyot upslope, which contains an uplifted and tilted oceanic section truncated by subaerial erosion. The farther, steeper slope of the guyot is one wall of a graben that strikes WNW-ESE across the crest of the Rise, between other guyots with similar depths to top. A short volcano-tectonic event, interpreted as passage over a midplate hot spot and probably unique in the history of the Rise, affected the entire crestal area. This hot spot is probably the same that produced the second, 80-50 Ma magmatic episode in Brazil, but it is distinct from the present Tristan hot spot that produced the Rise originally.

8) A subsidence model for the Rio Grande Rise uses these data on the age and origin of the basal volcanics at Site 516, as well as the nature and age of the middle
Eocene off-axis event. The model includes an oceanic, (age) ${ }^{1 / 2}$ thermal isostatic subsidence but takes account of the hot-spot environment of the original subaerial spreading center and considers the effects of subaerial isostatic subsidence. It incorporates the middle Eocene event as partly a thermal rejuvenation (thinning) of the lithosphere, which is reversible, and partly a compositional change, which is not.

9) The subsidence model takes into account both sediment compaction and isostatic compensation for sediment load by making use of the excellent set of physical properties data from Site 516, progressively unloading the sedimentary section up a load-depth curve constructed from them. Because of the possibility of other sediments occurring beneath the basalt at the base of Hole $516 \mathrm{~F}$, the effects of "basement compaction" are computed and shown to be less than $50 \mathrm{~m}$. A similar limit is attributed to the effects of using a local rather than regional isostatic response of the lithosphere to sedimentation and erosion at Site 516 and in surrounding areas. The subsidence model also uses Pitman's (1978) smooth curve of eustatic sea level change.

10) The resulting subsidence curve for Site 516 starts at $180 \mathrm{~m}$ above sea level, $84.5 \mathrm{Ma}$ ago, passes through sea level $0.5 \mathrm{Ma}$ later, and subsides to $1260 \mathrm{~m}$ in the $\mathrm{Pa}$ leocene, before rising rapidly to $600 \mathrm{~m}$ in the early middle Eocene and then subsiding more gently to its present depth of $1313 \mathrm{~m}$. If we assume that, after the middle Eocene, the guyot upslope from Site 516 followed a similar thermal subsidence curve, its submergence below sea level $35 \mathrm{Ma}$ ago is compatible with early Oligocene shallowwater fauna found downslope near Site 357.

11) A similar subsidence history is applied to Site 357 , so that the independent data set of paleoecologic depth estimates from both sites may be compared with the tectonic subsidence model. The paleoecologic estimates are generally deeper than the tectonic estimates at both sites, and it is difficult to understand how the tectonic model may be modified sufficiently to make it compatible. The cause of the discrepancy may lie in delays and difficulties in the precise correction for the effects of thermal subsidence and sediment compaction at comparison sites elsewhere in the world. For this effort, Site 516 may provide a new and useful datum, even though some modification of this tectonic model may yet be required.

\section{ACKNOWLEDGMENTS}

I am very grateful for the chance to have taken part in DSDP Leg 72 , and for the considerable friendly help received beforehand, aboard ship, and afterwards from DSDP and Global Marine personnel. I would also like to thank the many people whose very effective scientific work for Leg 72 I have been able to use in this synthesis, and my fellow co-chiefs, Dave Johnson and Rick Carlson, for helping arrange for that same work to be carried out in the first place and for many useful discussions. Bill Coulbourn made many suggestions that improved the text.

\section{REFERENCES}

Barker, P. F., 1979. The history of ridge-crest offset at the FalklandAgulhas Fracture Zone from a small-circle geophysical profile. Geophys. J. R. Astron. Soc., 59:131-145. 
Benson, R. H., 1977. The Cenozoic ostracode faunas of the São Paulo Plateau and the Rio Grande Rise (DSDP Leg 39, Sites 356 and 357). In Supko, P. R., Perch-Nielsen, K., et al., Init. Repts. DSDP, 39: Washington (U.S. Govt. Printing Office), 869-883.

Black, R., and Girod, M., 1970. Late Palaeozoic to Recent igneous activity in West Africa and its relationship to basement structure. In Clifford, T. N., and Gass, I. C. (Eds.), African Magmatism and Tectonics: Edinburgh (Oliver and Boyd), pp. 185-210.

Bodvarsson, G., and Walker, G. P. L., 1964. Crustal drift in Iceland. Geophys. J. R. Astron. Soc., 8:285-300.

Brotchie, J. F., 1971. Flexure of a liquid-filled spherical shell in a radial gravity field. Mod. Geol., 3:15-23.

Campos, C. W. M., Ponte, F. C., and Miura, K., 1974. Geology of the Brazilian continental margin. In Burk, C. A., and Drake, C. L. (Eds.), The Geology of Continental Margins: New York (SpringerVerlag), pp. 447-461.

Cande, S. C., and Rabinowitz, P. D., 1978. Mesozoic sea floor spreading bordering conjugate continental margins of Angola and Brazil. Offshore Technol. Conf. Proc., 3:1769-1776.

1979. Magnetic Anomalies of the Continental Margin of Brazil. Map Series, Am. Assoc. Pet. Geol., Tulsa, Oklahoma.

Chase, C. G., 1978. Plate kinematics: the Americas, East Africa and the rest of the world. Earth Planet. Sci. Lett., 37:355-368.

Crough, S. T., 1978. Thermal origin of mid-plate hot-spot swells. Geophys. J. R. Astron. Soc., 55:451-469.

Crough, S. T., and Thompson, G. A., 1976. Numerical and approximate solutions for lithospheric thickening and thinning. Earth Planet. Sci. Lett., 31:397-402.

Dahlen, F. A., 1981. Isostasy and the ambient state of stress in the oceanic lithosphere. J. Geophys. Res., 86:7801-7807.

Davis, E. E., and Lister, C. R. B., 1974. Fundamentals of ridge crest topography. Earth Planet. Sci. Lett., 21:405-413.

Detrick, R. S., and Crough S. T., 1978. Island subsidence, hot spots and lithospheric thinning. J. Geophys. Res., 83:1236-1244.

Detrick, R. S., and Watts, A. B., 1979. An analysis of isostasy in the world's oceans. 3. Aseismic ridges. J. Geophys. Res., 84: $3637-3653$.

Egloff, J., and Johnson, G. L., 1979. Erosional and depositional structures of the southwest Iceland insular margin: thirteen geophysical profiles. In Watkins, J. S., Montadert, L., and Dickerson, P. W. (Eds.), Geological and Geophysical Investigations of Continental Margins: Tulsa, Oklahoma (Am. Assoc. Pet. Geol. Mem.), 29:43-63.

Fodor, R. V., Husler, J. W., and Keil, K., 1977. Petrology of basalt recovered during DSDP Leg 39B. In Supko, P. R., Perch-Nielsen, K., et al., Init. Repts. DSDP, 39: Washington (U.S. Govt. Printing Office), 513-523.

Fodor, R. V., Husler, J. W., and Kumar, N., 1977. Petrology of volcanic rocks from an aseismic rise: implications for the origin of the Rio Grande Rise, South Atlantic Ocean. Earth Planet. Sci. Lett., $35: 225-233$.

Fodor, R. V., Keil, K., Husler, J. W., and McKee, E. H., 1977. Petrology and $\mathrm{K}-\mathrm{Ar}$ age of volcanic tuff and ash from the Walvis seamount province, DSDP Site 359, Leg 39. In Supko, P. R., PerchNielsen, K., et al., Init. Repts. DSDP, 39: Washington (U.S. Govt. Printing Office), 525-536.

Fodor, R. V., and Thiede, J., 1977. Volcanic breccia from DSDP Site 357: implications for the composition and origin of the Rio Grande Rise. In Supko, P. R., Perch-Nielsen, K., et al., Init. Repts. DSDP, 39: Washington (U.S. Govt. Printing Office), 537-543.

Gamboa, L. A. P., and Rabinowitz, P. D., 1981. The Rio Grande Fracture Zone in the western South Atlantic and its tectonic implications. Earth Planet. Sci. Lett., 52:410-418.

Gidskehaug, A., Creer, K. M., and Mitchell, J. G., 1975. Palaeomagnetism and $\mathrm{K}$-Ar ages of the South-West African basalts and their bearing on the time of initial rifting of the South Atlantic Ocean. Geophys. J. R. Astron. Soc., 42:1-20.

Hardenbol, J., Vail, P. R., and Ferrer, J., in press. Interpreting subsidence history and sea-level changes of passive margins from seismic and biostratigraphy. Hedberg Conference Proceedings.

Hart, S. R., and Staudigel, H., 1978. Oceanic crust: age of hydrothermal alteration. Geophys. Res. Lett., 5:1009-1012.

Heestand, R. L., and Crough, S. T., 1981. The effect of hot spots on the oceanic age-depth relation. J. Geophys. Res., 86:6107-6114.
Hinz, K., 1981. A hypothesis on terrestrial catastrophes: wedges of very thick oceanward dipping layers beneath passive continental margins. Geol. Jahrb. Reihe E, 22:3-28.

Hinz, K., and Krause, W., 1982. The continental margin of Queen Maud Land, Antarctica: seismic sequences, structural elements and geological development. Geol. Jahrb. Reihe E, 23:17-41.

Horowitz, D. H., 1976. Mathematical modelling of sediment accumulations in prograding deltaic systems. In Merriam, D. F. (Ed.), Quantitative Techniques for the Analysis of Sediments: London (Pergamon), pp. 105-119.

Houtz, R. E., Ludwig, W. J., Milliman, J. D., and Grow, J. A., 1977. Structure of the northern Brazilian continental margin. Geol. Soc. Am. Bull., 88:711-719.

Humphris, S. E., and Thompson, G., 1982. A geochemical study of rocks from the Walvis Ridge, South Atlantic. Chem. Geol., 36: 253-274.

Johnson, D. A., and Peters, C. S., 1979. Late Cenozoic sedimentation and erosion on the Rio Grande Rise. J. Geol., 87:371-392.

Kumar, N., 1979. Origin of "paired aseismic rises": Ceara and Sierra Leone rises in the equatorial, and the Rio Grande Rise and Walvis Ridge in the South Atlantic. Mar. Geol., 30:175-191.

Kumar, N., and Gamboa, L. A. P., 1979. Evolution of the São Paulo Plateau (southeastern Brazilian margin) and implications for the early history of the South Atlantic. Geol. Soc. Am. Bull., 90: 281-293.

LaBrecque, J. L., and Hayes, D. E., 1979. Sea floor spreading history of the Agulhas basin. Earth Planet. Sci. Lett. 45:411-428.

Ladd, J. W., 1974. South Atlantic sea floor spreading and Caribbean tectonics [Ph.D. thesis]. Columbia University, New York.

Le Douaran, S., and Parsons, B., 1982. A note on the correction of ocean floor depths for sediment loading. J. Geophys. Res., 87: 4715-4722.

Leyden, R., Asmus, H., Zembruscki, S., and Bryan, G., 1976. South Atlantic diapir structures. Am. Assoc. Pet. Geol. Bull., 60: 196-212.

Lowrie, W., and Alvarez, W., 1981. One hundred million years of geomagnetic polarity history. Geology, 9:392-397.

McDowell, S., Kumar, N., Jacobi, R. D., Johnson, D. A., and Bunce, E. T., 1977. Regional setting of Site 357, north flank of Rio Grande Rise. In Supko, P. R., Perch-Nielsen, K., et al. Init. Repts. DSDP, 39: Washington (U.S. Govt. Printing Office), 955-970.

Mascle, J., and Phillips, J., 1972. Magnetic smooth zones in the South Atlantic. Nature, 240:80-84.

Moore, T. C., Jr., Rabinowitz, P. D., et al., 1983. DSDP Init. Repts., 74: Washington (U.S. Govt. Printing Office).

Mutter, J. C., Talwani, M., and Stoffa, P. L., 1982. Origin of seaward-dipping reflectors in oceanic crust off the Norwegian margin by "subaerial sea-floor spreading." Geology, 10:353-357.

Ness, G., Levi, S., and Couch, R., 1980. Marine magnetic anomaly time-scales for the Cenozoic and Late Cretaceous: a précis, critique and synthesis. Rev. Geophys. Space Phys., 18:753-770.

Ninkovich, D., Sparks, R. S. J., and Ledbetter, M. T., 1978. The exceptional magnitude and intensity of the Toba eruption, Sumatra: an example of the use of deep-sea tephra layers as a geological tool. Bull. Volcanol., 41:286-303.

Parker, R. L., and Oldenburg, D. W., 1973. Thermal model of ocean ridges. Nature Phys. Sci., 242:137-139.

Parsons, B., and Sclater, J. G., 1977. An analysis of the variation of ocean floor bathymetry and heatflow with age. J. Geophys. Res., 82:803-827.

Pitman, W. C., III, 1978. Relationship between eustasy and stratigraphic sequences of passive margins. Geol. Soc. Am. Bull., 89: 1389-1403.

Ponte, F. C., and Asmus, H. E., 1976. The Brazilian marginal basins. Current state of knowledge. An. Acad. Bras. Cienc., 48(suppl.):215-239.

Rabinowitz, P. D., 1976. Geophysical study of the continental margin of southern Africa. Geol. Soc. Am. Bull., 87:1643-1653.

Rabinowitz, P. D., and LaBrecque, J. L., 1979. The Mesozoic South Atlantic Ocean and evolution of its continental margins. J. Geophys. Res., 84:5973-6002.

Richardson, S. H., Erlank, A. J., Duncan, A. R., and Ried, D. L., 1982. Correlated $\mathrm{Nd}, \mathrm{Sr}$ and $\mathrm{Pb}$ isotope variation in Walvis Ridge 
basalts and implications for the evolution of their mantle source. Earth Planet. Sci. Lett., 59:327-342.

Ridley, W. I., Watkins, N. D., and Macfarlane, D. J., 1974. The oceanic islands: Azores. In Nairn, A. E. M., and Stehli, F. G. (Eds.), The Ocean Basins and Margins. 2. the North Atlantic: New York (Plenum), 445-483.

Roberts, D. G., Schnitker, D., and Shipboard Scientific Party, 1982. Leg 81 drill margin, Rockall Plateau. Geotimes, 27(9):21-23.

Robertson, A. H. F., and Stillman, C. J., 1979. Submarine volcanic and associated sedimentary rocks of the Fuerteventura Basal Complex, Canary Islands. Geol. Mag., 116:203-214.

Schilling, J. G., Kingsley, R., Humphris, S. E., and Thompson, G., 1981. Tristan da Cunha hot spot. EOS Trans. Am. Geophys. Union, 62:424.

Sclater, J. G., Anderson, R. N., and Bell, M. L., 1971. Elevation of ridges and evolution of the central eastern Pacific. J. Geophys. Res., 76:7888-7915.

Sclater, J. G., and Christie, P. A. F., 1980. Continental stretching: an explanation of the post-mid-Cretaceous subsidence of the central North Sea basin. J. Geophys. Res., 85:3711-3739.

Sclater, J. G., Hellinger, S., and Tapscott, C., 1977. The paleobathymetry of the Atlantic Ocean from the Jurassic to the present. J. Geol., 85:509-552.

Sclater, J. G., and McKenzie, D. P., 1973. Palaeobathymetry of the South Atlantic. Geol. Soc. Am. Bull., 84:3203-3216.

Searle, R., 1980. Tectonic pattern of the Azores spreading centre and triple junction. Earth Planet. Sci. Lett., 51:415-434.

Siedner, G., and Miller, J. A., 1968. K-Ar age determinations on basaltic rocks from south-west Africa and their bearing on continental drift. Earth Planet. Sci. Lett., 4:451.

Sliter, W. V., 1977. Cretaceous benthic foraminifers from the western South Atlantic Leg 39, DSDP. In Supko, P. R., Perch-Nielsen, K., et al., Init. Repts. DSDP, 39: Washington (U.S. Govt. Printing Office), 657-697.

Stillman C. J., Furnes, H., LeBas, M. J., Robertson, A. H. F., and Zielonka, J., 1982. The geological history of Maio, Cape Verde Islands. J. Geol. Soc. London, 139:347-361

Supko, P. R., Perch-Nielsen K., et al., 1977. Init. Repts. DSDP, 39: Washington (U.S. Govt. Printing Office).

Talwani, M., Udintsev, G., et al., 1976. Init. Repts. DSDP, 38: Washington (U.S. Govt. Printing Office).

Tarney, J., Wood, D. A., Saunders, A. D., Cann, J. R., and Varet, J., 1980. Nature of mantle heterogeneity in the North Atlantic: evidence from deep sea drilling. Phil. Trans. R. Soc. London A, 297:179-202.

Thiede, J., 1977. Subsidence of aseismic ridges: evidence from sediments on Rio Grande Rise (southwest Atlantic Ocean). Am. Assoc. Pet. Geol. Bull., 61:929-940.

Tjalsma, R. C., and Lohmann, G. P., in press. Paleocence-Eocene bathyal and abyssal benthic foraminifera from the Atlantic Ocean. Micropaleontology, Spec. Publ. 4.

Trehu, A. M., 1975. Depth versus (age) ${ }^{1 / 2}$ : a perspective on mid-ocean rises. Earth Planet. Sci. Lett., 27:287-304.

Uchupi, E., 1979. The Bathymetric Atlas of the Atlantic, Caribbean and Gulf of Mexico (revised ed.): Woods Hole, MA (Woods Hole Oceanographic Institution), Reference 71-72.

Vail, P. R., and Hardenbol, J., 1979. Sea-level changes during the Tertiary. Oceanus, 22:71-79.

Vail, P. R., Mitchum, R. M., Jr., and Thompson, S., III, 1977. Seismic stratigraphy and global changes of sea level. Part 4. Global cycles of relative changes of sea level. In Payton, C. E. (Ed.), Seismic Stratigraphy: Applications to Hydrocarbon Exploration: Tulsa, Oklahoma (Am. Assoc. Pet. Geol.), pp. 83-97.

Vail, P. R., and Todd, R. G., 1981. Northern North Sea Jurassic unconformities, chronostratigraphy and sea-level changes from seismic stratigraphy. In Illing, L. V., and Hobson, G. D. (Eds.), Petroleum Geology of the Continental Shelf of Northwest Europe: London (Heyden), pp. 216-235.

Vogt, P. R., and Johnson, G. L., 1975. Transform faults and longitudinal flow below the midoceanic ridge. J. Geophys. Res., 80: $1399-1428$.

Watts, A. B., 1982. Tectonic subsidence, flexure and global changes of sea level. Nature, 297:469-474.

Watts, A. B., Bodine, J. H., and Steckler, M. S., 1980. Observations of flexure and the state of stress in the oceanic lithosphere. $J$. Geophys. Res., 85:6369-6376.

Wilson, J. T., 1965. Evidence from ocean islands suggesting movement in the earth. Phil. Trans. R. Soc. London, 258:145-167.

Wood, D. A., 1979. A variably veined suboceanic upper mantle; genetic significance for mid-ocean ridge basalts from geochemical evidence. Geology, 7:499-503.

Date of Initial Receipt: October 15, 1982 